ISABEL MARIA TEIXEIRA BICUDO PEREIRA

- EDUCADOR DE SAODE POBLICA

EM UM SISTEMA DE EDUCAÇÃO

Monografia apresentada à

Faculdade de Saúde Públi-

ca da Universidade de São Paulo, para obtenção do ti tulo de Mestre em Saúde P $\underline{\underline{I}}$ blica.

São Paulo

1977 


\section{A Cläudia,}

minha fithe. 


\section{AGRADECIMENTOS}

Quero deixar expresso meus agradecimentos às seguintes pessoas, que contribuiram de forma definitiva na elaboração do presente estudo:

- Profa. Dra. Ruth Sandoval Marcondes, pela orientaçảo, pelos ensinamentos e sugestöes, pelo incen tivo amizade;

- Prof. Or. Cornélio Pedroso Rosenburg, Nelly Martins Ferreira Candeias, William Moffitt Harris e Dr. Carlos Eduardo de Mattos Bicudo, que de várias formas e em momentos diferentes da elaboração desta monografia, partilharam comigo seus co nhecimentos, tempoe, principalmente, amizade;

- Sra. Leda Corrâa porto de Campos Camargo e Srta. Dalsy Pires Noronha, bibliotecárias da Faculdade de Saúde Püblica da Universidade de São Paulo, pe la revisão das citaçóes bibliográficas. 
o presente trabalho fol subvenciona do parcialmente pela Coordenação do Aper feiçoamento de Pessoal de Nivel superior (CAPES), através de concessão de Bolsa de Estudos para Pós-Graduação (Processo SBP n? $003183 / 74$ ). 
INDICE

Pág •

RESUMO

CAPITULO I - ASPECTOS HISTORICOS DA EDUCAÇÃO EM SAODE PUBLICA $\ldots \ldots \ldots \ldots \ldots$

1. A Educação em Saúde Pūblica no Mundo.

2. A Educação em Saúde Pública no Brasil

CAPITULO II - CONCEITUAÇÃO $\ldots \ldots \ldots \ldots$

CAPITULO III - A SECRETARIA MUNICIPAL DE EDUCAÇÃO DO MUNICIPIO DE SÃO PAULO ..

1. Aspectos relativos à população escolar do Município de São Paulo ......

2. A Educação em Saúde na Secretaria Municipal de Educação

CAPITULO IV - O EDUCADOR DE SAODE PÓBLICA NA SECRETARIA MUNICIPAL DE EDUCAÇÃO.

CONCLUSÕES 


\section{RESUMO}

Apresenta-se, inicialmente, alguns aspec tos históricos da Educação em Saúde pública, desde seus primórdios, até os tempos atuais, quando já con ta com um profissional especializado - o educador de saüde püblica.

Trata-se dos conceitos de Saúde, Educa ção. Educação em Saúde pública e Educação em Saúde na escola, bem como se discute seus objetivos.

Relata-se, também, a situaçäo atual da Se cretaria Municipal de Educação da Prefeitura de São Paulo, no que se refere à Educação em Saúde.

Finalmente, estima-se o número minimode educadores de saúde pública necessários à Secretaria, visando sua programação, e sugere-se linhas ge rals para sua atuação. 


\section{INTRODUÇAO}

A preocupação com a problemática da saüde em vários paises, entre os quais o Brasil, levou ao desenvolvimento de estudos dos recursos humanos necessários para a área da Saúde pública. Entre es tes contam-se os relativos ao profissional que atua na área da Educą̧ão em Saúde Püblica, denominado no Brasil de "educador de saúde pública".

o educador de saúde pública é um profissional novo, relativamente desconhecido no nosso meio, que vem de modo gradual se firmando na área da saúde comunitária, bem como na da saúde escolar.

São inümeros os trabalhos na literatura internacional, particularmente na URSS e EUA, que relatam experiências do educador de saúde püblica nos mais diversos campos da Saúde Pública. No Bra sil, onde o educador de saúde pública é um profissional de formag̨a recente, datando sua preparação de 1967, são ainda pouco numerosos os trabalhos re lacionados ao aseunto.

Este estudo tem, pois, por objetivo, anaLisar a importáncia da Educą̧ão em Saúde como par 
te do curriculo pleno de primeiro grau e, particularmente, a participasão do educador de saüde $p \bar{u}-$ blica nos programas desenvolvidos pela secretaria Municipal de Educąão da Prefeitura de são Paulo. Sugere ainda formas para sua atuagão e propõe o nú mero de profissionais necessários para atender às necessidades minimas atuais da Secretaria na ärea da Educą̧ão em Saúde Pübrica. 
CAPITULO I

ASPECTOS HISTORICOS DA EDUCAÇAO EM SAODE POBLICA 
CAPITULO I

ASPECTOS HISTORICOS DA EDUCAÇAO EM SAODE POBLICA

1. A EDUCAÇÃO EM SAODE POBLICA NO MUNDO

- IDADE ANTIGA

Para entendermos os problemas de nossa própria sociedade e sermos capazes de desempenhar. um papel inteligente na nossa civilização é preciso ter senso de continuidade no tempo e consciên-. cia de que ninguém pode avançar no futuro sem olhar atentamente para o passado; é preciso conhecer o passado e alicerçado nele, conduzir o presen te ${ }^{40}$. "O estudo da história da humanidade revela a grande herança que recebemos do passado em matéria de educação sanitárian27. Esta afirmação, completada com a de que a Educação em saúde sempre es teve intimamente ligada à Saúde Pública, leva-nos a buscar as origens da Educação em Saúde nas da sạ 
úde pública, isto é, na própria história da humani dade.

De acordo com ROSEN40, as origens da Saú de pública remontam há mais ou menos 4.000 anos. Es cavações realizadas ao norte da India revelaram a existência de uma civilização antiquíssima, cujas cidades eram conscienciosamente planejadas, construídas em quarteirōes retangulares com ruas a mplas, pavimentadas e drenadas por sistema de esgoto coberto. As rulnas de Tel-el-Amarna e Kahum, no Egito, revelam situação semelhante.

De certa forma, a higiene e a limpeza es tiveram ligadas ao homem desde sua ortgem, e por mui to tempo permaneceram relactonadas à religião. A pu reza era elemento indispensável aos homens para se apresentarem frente a seus deuses. E exatamente a estes é que se atribuia, até o inicio da civilização grega, a responsabilidade pelo aparecimento de doenças. Foram os gregos os primeiros a suspeitar que essas crenças eram falsas, começando a se preo cupar com a 1nvestigação das causas das doenças. ES sa preocupação foi se intensificando até que, nos 
séculos IV e V a.C., tentaram a elaboração de uma teoria sobre a etiologia das doenças.

Apesar da evidente contribuição de outros povos, sem dúvida alguma três grandes fontes colaboraram para que se chegasse ao atual panorama de saúde: Israel, Grēcia e Roma ${ }^{8}$.

Os cinco livros de Moisēs contêm inúmeros preceitos que podem ainda hoje ser considerados atuais em Saūde pública. No Deuteronômio* 23, v. 12-13, por exemplo, encontramos: "Haverá fora do acampamento um lugar retirado, aonde poderás di rigir-te. Terás contigo, em tuas bagagens, uma pá de que te servirás para abrir um buraco quando fores assentar-te lá fora e, partindo, cobrirás com terra os teus excrementos". Estas e algumas outras referências bíblicas sobre pureza e rituais de limpeza marcaram os hebreus e, assim, muito cedo encon tramos em sua cultura, vestígios de Educação em Sa

deuteronomio - In: bíblia Sagrada, 3a. ed., São Paulo, Ed. Ave-Maria, 1961, P.244. 
úde Pública. No Levitico* 15, v. 3-13, aparece a seguinte citação sobre gonorréia: "Todo o homem que tem gonorréia será por isso mesmo impuro. A im pureza está no fluxo: quer sua carne deixe correr o fluxo, quer o retenha, há impureza. Qualquer cama em que se deitar aquele que tem gonorrëia, bem como qualquer cadeira em que ele se sentar, será im pura. Quem tocar sua cama lavarã suas vestes, banhar-se-á em āgua e ficará impuro até a tarde. Quem se assentar na cadeira onde esteve um homem atacado de gonorréia, lavará suas vestes, banhar-séá em água e ficará impuro até a tarde. Aquele que tocar o seu corpo, lavará suas vestes, banhar-se-á em àgua, e ficará impuro até a tarde. Todo o que tocar alguma coisa que tenha estado debaixo dele, fi cará impuro até a tarde; quem transportar algumas dessas coisas lavará suas vestes, banhar-se-à em água e ficará impuro até à tarde. Aquele que for tocado pelo homem que tiver gonorréia, antes de ter es te lavado as mãos em ãgua, lavará suas vestes, ba-

* Levitico - In: Bíblia Sagrada, 3a. ed., São Pau10, Ed. Ave-Maria, 1961, p. 162. 
nhar-se-á em água e ficará impuro até à tarde. Todo o recipiente de terra tocado por esse homem será quebrado e todo vaso de madeira será lavado com água. Quando se tiver purificado aquele que tem gonorréia, contará sete dias para sua purificação; lavará suas vestes, banhar-se-à em água corrente e serà puro".

E impressionante a percepção dos israeli tas que, mais ou menos 3.000 anos antes da descoberta do agente etiológico da gonorréia, compreenderam claramente três dos principais elos da cadeia de transmissão de doenças: a infecção pelo contato, a desinfecção dos contatos e o papel desempenhado pelos fómites.

o Novo Testamento, baseado na doutrina de Cristo, ao contrário do Antigo, enfoca exclusivamente o bem-estar social e emocional. O amor ao pró ximo (restrição da agressão), a aceltação e o cari nho para com as crianças (segurança emocional), a confissão (catarse) são pontos que podem perfeitamente ser apoiados pelas mais modernas teorias psi cológicas. Quanto aos gregos e romanos, ambos pos 
suiam interesse marcante pelo bem-estar fisico $0^{40}$

Roma deixou grande legado no campo da sạ úde representado pela preocupação constante com abastecimento d'água. Os romanos foram engenheiros, administradores e construtores excelentes, superan do os gregos nesse campo. Seus costumes eram ricos no que se refere à higiene pessoal: banhos, pu rificação das mãos antes das refeiçōes, regime de vida. O conhecimento de recursos para a promoção da saúde e o tratamento de doenças constituiam ele mentos integrantes da educação do cidadão e do ofi cial romanos (herança dos gregos). Documentos com pilando todos esses conhecimentos atravessaram séculos, chegando até a Renascença. Dentre esses podemos citar a "Hygieia" de Claudius Galen(129 d.C.), que recomendava dieta, enfatizando a importância dos banhos e exercicios físicos. Realmente, era nas casas de banho que se discutia, analisava e ensina va saúde.

Quanto à Grécia, tanto em Creta como em Tróia, o sistema de abastecimento de água potável 
era fato comum, assim como a disposição do $11 \times 0$ e - sistema de drenagem de esgotos. Os gregos culti vavar o atletismo, fazendo dos exercicios fisicos - centro de suas atividades. Um corpo saudável se constituia em objetivo de vida para eles, dal seu interesse pela cura de doenças. Sua medicina, entretanto, nunca foi exclusivamente curativa, sendo dada grande importância aos assuntos de higiene pa ra a preservação da saũde. Ariphron, poeta grego, dizia em um poema: "Saúde, o mais antigo dos deuses"40. Entretanto, a vida saudável na Grécia era privilégio de uma classe superior minoritäria, cuja vida ociosa se alicerçava em uma economia escrá vai isto é evidente na literatura médica grega, que se preocupava grandemente com a saúde dos aristocratas e quase nunca com os problemas de saúde dos trabalhadores. Com a queda da civilização grecoromana todo esse acervo de conhecimentos relativos à saúde fol se dilulndo, acabando por ser esquecido.

- IOADE mEdIa

Na Idade Média ${ }^{40}$, período compeendendo mais 
ou menos 1.000 anos, volta a reinar o concelto de doenças ligadas ao sobrenatural, tanto entre cristãos como entre pagãos. As sucessivas invasōes dos bárbaros, destruindo e saqueando cidades, alladas a outros acontecimentos politicos determinarama de sintegração da saúde pública como organização e co mo prática. Durante essa época difícil do ponto de vista sanitário é nos mosteiros que se vão encontrar algumas atividades voltadas para a saúde. Ao que se sabe, os mosteiros foram, durante a Idade Mé dia, os depositários do conhecimento dos povos antigos, inclusive no campo da saúde. Constituiam-se nessa época em grandes comunidades e, para que a ví da em comum fosse possivel, começaram por estabele cer medidas que favoreciam a saúde da própria comu nidade, tais como, abastecimento de água potável, destino adequado de dejetos humanos, ventilação adequada nos dormitórios. o sucesso dessas medidas ultrapassou os limites dos mosteiros e passou a in fluenciar, positivamente, outras comunidades da època. E desse período que chegaram até nós alguns dos primeiros enfoques de Educação em Saúde Pública, através de documentos conhecidos como regimes ${ }^{35}$. 
Esses regimes eram escritos em versos de fãcil memorização. Assim como os menestrëis levavam notícias em suas canções, professores viajantes repetiam versos que ensinavam como viver sadia mente. Essa literatura enfatizava higiene pessoal, englobando três assuntos: alimentação, habitação e corpo humano. Quanto mais curtos e fácels de memo rizar, mais populares esses versos se tornavam. Hou ve, entretanto, uma exceção nesse sentido, o regime proposto por Galeno; possuindo cerca de 10.000 palavras, assim mesmo tornou-se famoso. Parece que tal fato se deve à maneira dogmática com que foi re digido. Dentre todos esses regimes primitivos, 0 mais famoso foi o "Regimen Sanitatis Salernitanum", cuja orlgem remonta aos séculos XII ou XIII, sendo reeditado até o século XIX (1846). Durante esse tempo foi reeditado pelo menos 240 vezes, sendo tra duzido para inúmeras linguas européias. Um trabaIho que perdurou por tanto tempo não pode ser menosprezado e, na verdade, os conselhos al oferecidos resistem ainda hoje ao progresso dos conhec1mentos no campo da saúde. Esses conselhos são relativos à prevenção da obesidade e das moléstias car 
dio-vasculares, bem como à promoção da saúde mental. o grande valor da escola de Salerno reside no reconhecimento da relação entre o comportamento do indivíduo e sua saúde.

Os educadores primitivos, embora empiricos, muitas vezes chegaram a conclusões que podem hoje ser mantidas por evidências científicas. Está nesse caso o livro de etiquetas, de origem italiana, "Galateo Della Casa" (1550), que preconizava os comportamentosà mesa que ainda hoje repetimos às nossas crianças.

Em sintese, durante vārios sēculos os re gimes se preocuparam em difundir preceitos de higie ne pessoal, higiene da habitação, nutrição, repouso, prevenção de certas moléstias, e com a promoção da saúde mental; entretanto, apesar de sua gran de popularidade, não hã evidência suficiente de que tenham sido realmente eficientes do ponto de vista da Educação em Saúde pública. E só no séaulo XVIII, com o Capitão Cook, que se realiza uma primelra ten tativa de implantação de medidas higiênicas preven tivas, com o objetivo de se evitar a perda de vi- 
das. Cook fol premiado com a "Copley Medal" da "Royal Soclety" da Inglaterra, em 1776, não só pe10 brilhantismo de suas pesquisas geográficas, mas tambérn por conseguir efetuar uma viagem ao redor do mundo sem perder um único homem, o que no seu tempo era praticamente impossível.

Segundo Simon, citado por PIRRIE \& DALZELL-WARD 35 , o Capitão Cook conseguiu essa vitória introduzindo medidas simples mas profundamente ino vadoras na vida de bordo, tais como: ventilacão dos conveses inferlores, fornalha acesa para secar rou pas e aquecer os homens após a lavagem dos conveses, fornecimento de comida fresca, incluindo verduras e frutas como medida preventiva do escorbuto, e racionalização do período de trabalho.

A implantação dessas medidas supōe um trạ balho educativo de alto nivel, uma vez que se cons tituiam em situação nova e em mudança de comportamento. Sem dúvida alguma foi necessária grande mo tivação para que essa nova situação fosse integrada à vida do pessoal de bordo. Dentro do quadro ge 
ral da Saúde pública é esta a primeira demonstração do princíplo de que Educação em Saúde implica em envolvimento da população para a qual se dest1na. De acordo com PIRRIE \& DALZELL-WARD, fol esse principio que bem mais tarde, no século XIX, velo influenciar o trabalho de Florence Nightingale. Pio netra em Enfermagem de Saúde Pública, foi ela a prí meira a advogar a utilização de visitadores treina dos para aconselhar mães em seus próprios domicilios; acreditava que se o visitador pudesse trabą Ihar com as mães, poderia conhecer mais profundamente as dificuldades enfrentadas pela clientela, ganhar sua conflança e assim o processo educativo se estabeleceria com bases mais sólidas ${ }^{35}$.

Durante o longo periodo abrangido pela I dade Média outros aspectos da Saúde Pública, como a implantação da quarentena, a expansão dos hospitais, a preocupação com assistência social e problemas sanitários da vida urbana, se constituiram en uma primeira tentativa de se resolverem os problemas de saúde das populaçōes. Do ponto de vista histórico, o mais importante è que no período me- 
dieval se desenvolveram os padrões bãsicos de idéias e práticas dentro dos quais a saúde pública funcio naria nos próximos 250 anos $^{40}$.

\section{- RENASCENÇA}

Durante o pontificado de Leão $x$, surge na Itálla Girolamo Fracastoro, médico, poeta e cientista, que entrevê, apesar das guerras e doenças da época, o surgimento de uma nova era, a Renascença.

Segundo ROSEN ${ }^{\circ}$, embora a Renascença se apresente sempre como uma fase brilhante, de grandes descobrimentos, no campo da Saúde pública ela é significativa não por seu esplendor, mas por ter sido o início de novo período da História, no qual a Saúde pública foi verdadeiramente impulsionada. Esse periodo testemunhou o nascer da civilização mo derna e o início da ciência moderna, com conseqten te influência sobre a Saúde Pública. Nesse período foram descobertos os microorganismos, embora sua relação com doenças infecto-contagiosas tenha permanecido desconhecida ainda por algum tempo; a pos 
sibilidade de contágio direto ou indireto atravēs de fómites e do ar fol percebida e apresentada por Fracastoro. Surgiram tambēm as primeiras tentativas no sentido de se utilizar a estatistica como ing trumento para se estudar uma população, assim como - relacionamento entre o estado de saúde de uma co munidade e sua situação politica. Inicialmente é William Petty, médico, economista e cientista, cria dor do termo estatística, que luta e defende a importância de se colecionarem dados sobre educação e doenças da população; mas é a seu amigo Joh n Graunt que se atribui a primeira grande contribuição a esse campo, através do livro "Natural and Po litical Observations upon the Bills of Mortality", em 1662 .

Os problemas de saúde enfrentados pelos centros urbanos dessa época foram muitos e de difí cil' solução. A limpeza das ruas, a disposição final do lixo, o problema de esgotos e do abastecimento de água, as doenças epidêmicas, são alguns dẹ les. 
Segundo ROSEN 40 , O período compreendido entre o inficio do século XVI e a metade do século XVIII (1500-1750) constitui um período de transi§̧ão. As grandes explosões cientificas dos séculos XVI e XVII estabeleceram os alicerces da clència mé dica no campo da anatomia e fisiologia. A observa ção e classificação tornaram possivel o reconhecimento preciso das doenças. Ao mesmo tempo, a possibilldade e importância da aplicação do conhecimento cientifico às necessidades de saúde das comu nidades começou a tomar forma ideal. Desenvolveuse um enfoque quantitativo dos problemas de saúde relacionado com as necessidades politicas e econô micas do Estado moderno. A idéia de que micro-organismos poderiam ser a causa de doenças contagiosas começou a assumir forma concreta. As comunida des do sëculo XVI, XVII e mesmo XVIII enfrentaram problemas de doenças epidêmicas, de adequação de cuidáas médicos, de saūde ambiental, tratando-os sob alguns aspectos da mesma maneira que as comuni dades do período medieval. Mas durante essa época, rica de problemas e também de novos conhecimentos, é que as bases para a implantação de uma nova era foram lançadas. 
- IDADE MOdERna e CONTEMPORANEA

Apōs a Renascença segue-se um período de aproximadamente 80 anos $(1750-1830)$ de grande progresso e desenvolvimento, principalmente no que diz respeito à saúde Pública. Alnda segundo ROSEN40, è nesse período de revoluções e restaurações, intensamente confuso do ponto de vista político, que a Europa se empenha em construir um futuro alicerçado em novas bases. As grandes revoluções politi cas na França e América, a ascensão e queda do império napoleônico, assim como o esforço em restaurar o antigo regime, são os mais importantes acontecimentos desse processo de mudança. Durante esses anos a Europa, embora com problemas diversos, de diferentes e complexos antecedentes e objetivos muitas vezes colidentes, manteve uma espécie multo tênue de unidade: a mudança era aceita como algo $\underline{1}$ nevitável. Nessa atmosfera germinaram as novas idélas que revolucionaram a Saúde pública no século $\mathrm{XIX}$. 
E nesse periodo que Jenner faz sua desco berta em relação à vacina anti-variólica, abrindo novos horizontes em relação às doenças infecto-con tagiosas; o valor desta descoberta, entretanto, só é realmente reconhecido em fins do século xIX, prin cipalmente com os trabalhos de Pasteur e Kock. Em bora soluçōes fossem sendo encontradas para os vários problemas decorrentes do complexo binômio saúde-doença, numerosos outros permaneceram sem solu u ção, enquanto novos surgiam, decorrentes do desenvolvimento da indústria.

A Revolução Industrial, que consistiu es senclalmente na mudança da produção industrial, as soclada ao aparecimento das máquinas movidas a vapor, encontrou a Inglaterra sem um sistema efetivo de governo local. Desse modo, enquanto de um lado floresciam as indústrias, de outro decaia e deterlorava-se a saúde e bem-estar dos trabalhadores. Essa situação, atuando como elemento de pressão, deu origem a iniciativas e protestos que se aglome raram, originando o Movimento de Reforma Sanitária. 
Esse movimento do século XIX começou na Inglaterra, uma vez que foi lá que se iniciou a Re volução Industrial e ocorreram os acontecimentos de la decorrentes. Uma análise histörica desse perío do revela que a França, a Alemanha e os Estados Unidos viveram os mesmos problemas que a Inglaterra, para os quais buscaram soluçōes semelhantes.

Em termos de morbidade e mortalidade pre coce, o preço pago pela industrialização foi muito alto; o objetivo do Movimento de Reforma Sanitária visava despertar na comunidade a preocupação pe la saüde de seus membros.

Como se pode perceber, a Educação em Saú de pública, embora não reconhecida ainda oficialmente, esteve sempre ligada à Saúde Pública como fä tor indispensável na consecução de objetivos relacionados com a melhoria do bem-estar dos individuos. No período entre o final do século XVIII e InIcio do século XIX, Educação em Saúde pública só era compreendida como divulgação de conhecimentos sobre saúde, através de publicações variadas como 
livros, almanaques, folhetos e periódicos. "Avis au peuple sur sa Santé", de S.A. TISSOT, escrito em 1762, em apenas 6 anos teve 10 edições publicadas somente na França. "Gesundheitskatechsmus", de B.C. FAUST, publicado em 1794, teve grande aceitação poo pular. Nos Estados Unidos, vários periódicos foram publicados no início do sēculo XIX com o objetivo de divulgar Educação em Saúde pública. O prí meiro, datando de 1806, foi o "Medical and Agricul tural Register", cujo conteúdo versava sobre higiene pessoal e assuntos referentes à agricultura. Em 1830, um grupo de médicos iniciou a publicação do "Journal of Health", tambēm de curta duração (4 anos) e que como o anterior, enfocava principalmente higiene pessoal. Os guias médicos a nivel popu lar eram muito comuns nessa época, e segundo ROSEN 40 - autor mais popular nesse campo foi William Bucha nan, escocês, autor de "Domestic Medicine" ou "The Family Physiclan", que foi publicado em 1769, com 19 ediçōes posteriores. Finalmente, não se pode delxar de citar Southwood SMITH, um dos mais at1vos reformadores ingleses no campo da Saüde Pübl1ca, que levou ao conhecimento do público o corpo hụ 
mano e suas funçöes, atravēs do livro "The Ph1loso phy of Health", em 1835. O periodo conpreendido en tre 1830 e 1875 é o que ROSEN40 denominou de "Perío do do Industrialismo e Movimento Sanitárion; 0 de senvolvimento industrial dessa época fol multo gran de e velo determinar a organização das indústrias em forma de sistema fabril, com todas as suas vantagens e desvantagens. A situação que se criou a partir desse momento obrigou as comunidades a buscar soluções para seus próprios problemas. Foi em Manchester, Inglaterra, que isto se evidenciou pela primeira vez. Uma série de surtos de febre tor nou a comunidade consciente da necessidade de encontrar meios para impedir o aparecimento e a propagação das doenças. O primeiro passo nesse sent1 do fol dado em 1795, com a criação do Conselho Voluntärio de saúde, em decorrência da rápida difusão da febre tifōide na região. Essa iniciativa, posteriormente, originou, entre 1830 e 1875 , pressões que visavam a organização de entidades sanitā rlas de âmbito estadual, nacional e internacional. Em 1848, graças ao trabalho de CHADWICK, principal mente, é criado na Inglaterra o Conselho Geral de 
Saúde, que constitui um marco na história da Saúde Pública, a despeito de sua breve existência (18481854) e das desvantagens sob as quais funcionou. Em 1879 é criado o Conselho Nacional de Saúde nos Estados Unidos da América, com função de assessorar os governos estaduais e federal no campo da saúde pública, assim como, de planejar a organização nacional da Saúde pública. Em 1883 o Conselho é extinto devido ao dificil manejo da estrutura administrativa, assim como por ter estimulado o antago nismo dos Estados, que sentiam que seus direitos es tavam sendo prejudicados pela ação do Conselho.

Como se percebe, os problemas sanitārios decorrentes da industrialização fizeram-se sentir da mesma forma em todos os países, à medida que o iam adotando. Foi na Alemanha, por volta de 1870, que Max von PETTENKAFER levantou a problemātica de que a saúde do indivíduo não era influenciada apenas pelo ambiente físico, mas também pelo meio social. Ele acreditava e pregava que a Saúde públi ca era de interesse da comunidade. Alimentado por esta conviç̧ão, desenvolveu um trabalho pioneiro so 
bre higiene da alımentação, do vestuário, da habitação, da água, do lixo, conseguindo fazer de Muni que uma cidade saudável. Por essa época, a contro vérsia sobre as doenças infecto-contagiosas, sua 으 rigem e transmissão, era sentida não mais a nivel nacional, mas internacional. A cooperação interna cional na prevenção de doenças transmissiveis tornou-se assunto de grande importância, até que, em 1851, a realização do primeiro Congresso Sanitário Internacional, em paris, veio tornar mais próxima a possibilldade da criação de uma organização internacional de saúde. A essa conferência compareceram representantes de vários países europeus. Co mo era de se esperar de um primeiro encontro inter nacional, em uma época de grandes controvérsias ci entificas, os trabalhos desenvolveram-se morosamen te, superando incontáveis problemas, até que se che gou à elaboração de uma série de normas que vieram constituir a primeira tentativa de elaboração de um Código Sanitário Internacional. Só em fins do século XIX, entretanto, o desenvolvimento da bacteriologia e imunologia veio abrir novos horizontes e oferecer reais possibilidades para um acordo no 
campo da Saúde Püblica.

Para se prevenir as doenças e promover a saúde é necessārio combater a ignorância. Esta ên fase que caracterizou um periodo, com inficio no sé culo passado, fazia acreditar ser a Educação em Sa ũde Pública a base dos programas de Saūde, const1tuindo um inicio indispensável para obtenção de èxito dos programas sanitários.

Nos paises europeus, assim como na Améri ca, foram vários os fatores que influenciaram o de senvolvimento maior ou menor da Educação em $S$ aúde Pública. Entretanto, foi nos EUA que ela atingiu até nossos dias, um maior grau de desenvolvimento. Tudo começou com um movimento multo importante na época, cujo objetivo era estudar as necessidades da criança e especialmente atividades relacionadas cam alimentação escolar, segurança, e saúde mental. Na segunda década do século XX, agências de saúde existentes na época resolveram organizar suas ativi dades e, como consequèncla dessa resolução, en 1911 e 1912 os Departamentos de Saúde de Nova Yorke Ch⿻ cago intciaram a publicaçāo de boletins. 
O boletim do Departamento de Nova York ti nha por objetivo contribuir para a educação dos pro fissionais médicos nos aspectos preventivos do seu trabalho diário. Em 1914, O Departamento de Saúde de Nova York criou o primeiro órgão de Educação em Saúde Pública na estrutura administrativa. A primelra Guerra Mundial veio, por sua vez, colaborar para o desenvolvimento da Educação em Saúde Pública. Necessidades de tempo de guerra, tais como o controle das doenças venéreas, especialmente entre - pessoal das forças armadas, aliadas ao progresso contínuo no campo da saúde infantil, vieram contrí buir para o reconhecimento da Educação em Saúde co mo a mals recente especialidade da saúde pública. Em 1918 é criada nos EUA a "Child Health Organization of América" (Organização Americana de Saúde da Criança), tendo à sua frente L. Emmet HOLT, pediatra, e Sally Lucas JEAN, enfermeira. Fo1 ela que, em 1919, em reunião patrocinada pela nova organiza ção, propôs o termo "Educação em Saũde" (Health Education). Desde então, Educação em Saúde passa a ter vida própria e em 1937 o governo americano reconhece publicamente sua importância, criando uma 
seção especializada dentro do United States Public Health Service 27 . Vagarosamente começaram a ser preparados recursos humanos para esse campo de tra balho. O primeiro a oferecer treinamento a nivel de graduação para educadores de saúde pública foi - Massachussets Institute of Technology, sob orien tação de Clair F. TURNER ${ }^{27}$. Essa iniciativa foi lo go seguida de outras; entretanto, estudo realizado em 1942 mostrou que existiam educadores de saúde püblica em apenas 13 Estados norte-americanos, atingindo um total de 44 profissionais. A partir dal, a formação desse pessoal passou a ser estimulada e um novo estudo, em 1947, veio revelarque dos 460 individuos trabalhando em Educação em Saũde Pú blica, 300 eram graduados por escolas de saúde pública, reconhecidas oficialmente. Em 1951 o número de profissionais, sempre em ascensão, justificou a crlação da soclety of Public Health Educators (SOPHE) 27 .

Na Europa o desenvolvimento da Educação em Saúde pública aconteceu de modo diferente, devi do às caracteristicas de seu próprio povo, sistema 
de governo e problemas de saúde. Com exceção da URSS, a Educação em Saüde püblica foi promovida por organizações independentes, tais como grupos de jo vens, sociedades anti-tuberculose e anti-alcoölica, cujos trabalhos eram desenvolvidos sem coordenação e com resultados bastante discutiveis. As ültimas décadas, entretanto, testemunharam o esforço de al guns paises no sentido de organizar suas atividades no campo da Educação em Saúde pública. Mesmo assim, a distância entre o ponto de desenvolvimento em que se encontram, e o alcançado pelos EUA, é muito grande.

Na Alemanha, a Educação em Saúde surgiu sob forma organizada com a constituição da "Deutsche Verein far Volkshygiene" (Sociedade Alemã para a Higiene Pública), em $1908^{40}$. Em 1919 surgem os "Landesausschllsse für higienische Volksbelchrung" (Comitês Estaduais para a Educação em Saúde Pública). Em 1920 essas sociedades são unificadas e cen tralizadas num comitê com sede em Dresden e depois em Berlim. Com o advento da II Guerra Mundial, e posterior divisão da Alemanha, o país é agitado por 
grandes mudanças. Em 1954 a Repüblica Federal Ale mã cria o Comitê Federal para Educação em Saúde Pú blica, subvencionado pelo governo, mas existindo co mo uma organização voluntāria. Seu objetivo e ra estimular individuos e grupos para atividades de saúde individual e comunitāria, assim como preparar material educativo. O educador de saúde públí ca è alnda desconhecido na Alemanha e até alguns a nos atrās a Educação em Saúde pública, embora oficialmente considerada uma função das agências de saúde, na prática era desenvolvida por organizaçöes voluntārias ${ }^{18}$.

Na França, Educação em Saúde é reconhecí da como função de agências oficiais de saúde. N a verdade, ela foi reconhecida oficialmente em $1924^{40}$, com a criação do "Office National d'Hygiene Sociale" (Departamento Nacional de Higiene Social), mais tarde substituído pelo "Centre National de l'Educa tion Sanitaire, Demographique et Sociale" (Centro Nacional de Educação em Saūde, Demogrāfico e Social), órgão do Ministērio de Saúde Pública, e cujo interesse é o estabelecimento de amplo programa de 
Educação em Saüde, a nível nacional, assim como a preparação de material educativo (impressos, folhe tos, cartazes, filmes). A nivel local, entretanto, a situação da Educação em Saúde pública varia de re gião para região, dependendo do interesse das agên cias oficiais pelo assunto. Em 1951 è criada en Pa ris a "Union Internationale pour l'Education Sanitaire Populaire" (União Internacional de Educação em Saúde Pública), cujo objetivo è a promoção e de senvolvimento da Educação em Saúde a nivel interna cional, atravēs, principalmente, da criação de comitês ou Sociedades Nacionais. Quanto ao educador de saúde pública, não existe ainda na França qualquer curso especializado para sua formação, embora grandes esforços nesse sentido tenham sido desenvolvidos por Lucien VIBOREL enquanto diretor do Cen tro Nacional de Educação em Saúde ${ }^{27}$.

Na Inglaterra a Educação em Saúde desenvolveu-se sob forma organizada, após a criação do "Central Council for Health Education" (Conselho Central de Educação em Saúde) em Londres, em 1927, reconhecido pelo Ministério da Saúde e autoridades 
locais. Sua função è dar assistência às autoridades locais na Inglaterra, Pais de Gales e Irlanda, em programas que envolvam aspectos educativos e m Saúde Pública. E também responsável pela publicação do periódico "Health Education Journal", do"Health Information Digest" e do "Quarterly News Bulletin". O educador de saúde pública passou a ser formado $\mathrm{n} a$ Inglaterra, a partir de 1954, pelo "Institute of Education" (Instituto de Educação), da Universidade de Londres ${ }^{27}$.

A URSS, é talvez, o pais que possui o me Ihor sistema integrado de Educação em Saúde Pública. Isso resulta, ao que tudo indica, do sistema prevalente de medicina socializada. Em 1893 a Edu cação em Saúde Pública foi introduzida nas escolas soviéticas ${ }^{40}$. Existem centros de Educação em Saúde Pública distribuídos por toda a URSS, que são di rigidos por leigos previamente treinados. O maior centro que a URSS possui é o Instituto Central de Pesquisa Cientifica em Educação em Saũde, sediado em Moscou, e que compreende três departamentos: Educą ção em Saúde na escola, Educação em Saúde no campo 
médico e profilático e Educação em Saũde nas indús trias. Esse Centro realiza pesquisas e avaliação de métodos e técnicas educativas, incluindo impren sa, rádlo e materiais visuais, assessora centros de Educação em Saúde pública e desenvolve programas de treinamento para especialistas da área eoutros profissionais de saúde. Para atingir seus objetivos - Centro conta com órgãos de saúde, principalmente os Centros de Educação em Saúde Pública. O primeiro desses centros foi criado em 1920 e, por volta de 1964 já somavam 360, atuando do nível federal a té o municipal. Sua principal função è a organiza ção, orientação e execução de todo trabalho de Educação em Saúde Pública. Na URSS a Educação em Sa úde Pública constitui uma atividade obrigatória de todos aqueles que trabalham no campo da Saúde $P \bar{u}-$ blica, tanto profissionais como leigos. O educador de saúde pública é preparado na URSS pelo Instituto Central de Pesquisa Cientifica em Educação em Saúde. 
2. A EDUCAÇÃO EM SAÓDE PÓBLICA NO BRASIL

- Brasil, ao tempo de sua descoberta e enquanto os conquistadores portugueses não $\circ$ penetraram com sua colonização, era de uma salubridade perfeita, afirmam BARBOSA e REZENDE ${ }^{2}$, acrescentando que todos os documentos de que se dispõem atestam o aspecto saudável, a beleza e a higiene do in dio brasileiro. A longevidade entre os nativos era comum. As terras e o clima brasileiros eram ti dos como saudáveis e favoräveis à saúde. As doenças não graçavam aqui. As únicas doenças consideradas como originárias da terra eram a malária, a bouba e a ancilostomose. Infelizmente, os colonizadores não souberam conservar as condições naturais encontradas no País. Não se apegavam à terra e não se preocupavam em preservá-la; não valorizâ vam a própria vida e, conseqtentemente, não davam valor à vida dos indios. Eram misticos, acostumados a atribuir as moléstias a fenômenos da natureza ou à ira divina. Seu objetivo era fazer fortu- 
na para gastá-la além-mar; por isso só viam no índio o escravo de que necessitavam para trabalhar as terras. Em 1555 a expedição de Villegagnon foi a mensageira de uma primeira epidemia, que seria seguida de inümeras outras. Essa primeira epldemia não fol identificada, embora responsável pela dizi mação de número imenso de selvagens. Entre todas as epidemias importadas, sem dưvida foi a variola que mais mortes e devastações causou entre a população daquela época. Surgindo aqui em 1563 pela primeira vez, só em 1804 começou a ser combatida com a vacina de Jenner, introduzida na Bahia e posteriormente no Rio de Janeiro e São Paulo². Na época em que escreveram seu livro (1909), comentaram BARBOSA e REZENDE estar o Brasil caminhando para a solução de seus problemas sanitārios; as doenças iam sendo cada vez mais controladas e estava cada vez. mais presente a noção da necessidade de um meio ambiente saudável para a vida do homem².

Segundo MARCONDES 27 , no Brasil, os primeiros vestígios de Educação em Saúde pública apareceram por volta de 1889, com a preocupação da en 
tão Diretoria Geral da Saúde Pública em informar a população, através de impressos, sobre as causas e prevenção da febre tiföide, tuberculose e peste que eram, naquela época, responsáveis por uma alta taxa de mortalidade na Capital do Império.

Simultaneamente, O Instituto de Higiene do Rio de Janeiro esforçava-se em oferecer aulas de higiene aos professores primários e alunos da Esco la Normal, assim como divulgar noçöes de higiene pes soal e da habitação à população em geral.

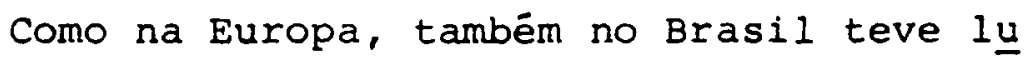
gar a fase de divulgação de conhecimentos sobre os aspectos etiológicos, preventivos e curativos das doenças. Um exemplo típico è o "Dicionário de Medicina Popular e das Sciencias Accessorias", de GER NOVIZ, editado pela sexta vez em 1890. Em 1920 é criado o Departamento Nacional de Saúde Pública, co mo örgão do Ministērio da Justiça e Negōcios Interiores, através do Decreto Federal ng 14.354. Em 1923, através do Decreto Federal no 16.300, é alte rado o Regulamento do Departamento Nacional de Saū 
de Pública, sendo-lhe atribulda a organização do "Serviço de Propaganda e Educação Sanitäria". E a primeira vez que a expressão "Educação Sanitária", trazida dos EUA pelo professor Geraldo Horácio de Paula Souza, em 1920, aparece na legislação ofici$a^{27}$. A evolução da sociedade brasileira obrigou a constantes mudanças e ajustamentos nos seus órgãos públicos. Assim, em 1930 fol criado o Ministério dos Negócios da Educação e Saúde pública, que englobava o Departamento Nacional de Saúde püblica, passando o Serviço de Propaganda e Educação Sanitā ria a constituir a Seção de Informação, Propaganda e Educação Sanitāria do mesmo Departamento. Em 1937 - Ministério é reorganizado e a Seção de Informação, Propaganda e Educação Sanitāria è substituỉda pelo Serviço de Propaganda e Educação Sanitāria. Em 1941, o Departamento Nacional de Saúde Pública sofre novas modificações, dessa vez com ampliação e intensificação de atividades que passaram a ser de senvolvidas a nivel nacional, a exemplo de outros Departamentos. Em 1953 surge o Ministério da Saúde, como resultado da cisão do Ministério da Educa ção e Saūde Pública. O Departamento Nacional de 
Saúde Pública passa a integrar o referido Ministério da Saúde, sem sofrer alterações em sua estrutụ ra. A $22 / 05 / 1970$, através do Decreto no $66.623^{11}$,é criada a Divisão Naclonal de Educação Sanitāría co mo resultado da transformação do Serviço Nacional de Educação Sanitária e subordinada ao Departamento Nacional de Profilaxia e Controle de Doenças na Secretaria de Saúde Pública. Sua finalidade è "es tabelecer as diretrizes bāsicas para os programas de Educação Sanitāria, coordenando e orientando sua aplicação no Ministério da Saúde; assessorar ärgãos públicos e entidades privadas na organização e fun cionamento de serviços e atividades de Educação Sa nitária; estudar e pesquisar, bem como incentivar, promover e colaborar no treinamento de pessoal. o Decreto no 74.891, de $13 / 11 / 1974^{12}$, extingue $\circ$ Departamento Nacional de Profilaxia e Controle de Do enças, Elcando as unldades que o integravam (inclü sive 0 DNES) subordinadas diretamente à secretaria de Saúde Püblica, que pelo mesmo Decreto passa a denominar-se Secretaria Nacional de Saúde.

Não se pode deixar de cltar, nesse cami- 
nhar histórico, a criação do Serviço Especial de Sa úde Püblica (SESP), por volta de 1942, atualmente transformado em Fundação. Desde a sua criação e a té o presente, uma das preocupações dessa entidade tem sido a Educação em Saúde pública. O êxito obtị do nos trabalhos realizados durante todos esses anos demonstra a eficiência da filosofia de trabatho adotada pelo referido örgão. A atuação da FSESP cobre grande parte do território brasileiro.

Em São Paulo, a Educação em Saúde Pública sem dúvida alguma foi impulsionada inicialmente por Geraldo Horácio de Paula Souza, posteriormente por Rodolfo dos Santos Mascarenhas e, mais tarde, por Ruth Sandoval Marcondes.

Por iniciativa de PAULA SOUZA foi criado, em 1924, o Curso de Educadores Sanitários no antigo Instituto de Higiene de São Paulo. Os candidatos ao curso eram selecionados entre professorespri mários regentes de classe, que vinham para o Insti tuto de Higlene receber treinamento em Educação em Saúde. Em virtude da não existência de enfermei- 
ras nos Centros de Saúde, criados por volta de 1927 em São Paulo, os educadores sanitários começaram a ser utilizados por esses Centros, com funções polí valentes. A partir de 1946, em decorrência da reforma universitária, candidatos portadores de diploma de curso secundário completo (clássico e cientifico) passaram também a ter acesso ao curso ${ }^{31}$.

Em 1958, sentindo a necessidade de avaliar o treinamento oferecido aos educadores sanitá rios, em termos de responsabilidades e funções no campo, a Faculdade de Higiene e Saúde Pública desig nou uma Comissão para realizar estudo do assunto, integrada por MARCONDES e RAHM ${ }^{31}$. Os resultados,pu blicados em 1959, revelaram que o educador sanitário "parece ser um funcionārio polivalente, não che gando suas funções a ser nem as da enfermeira de sá úde püblica, nem as da assistente social e nem as do educador de saúde pública tal como classificado pela OMS". O mesmo estudo, entre as conclusões apresentadas, levanta um problema cuja solução considera tão vital quanto complexa: com o desenvolvimento de especialidades como Enfermagem de Saúde 
pública, Serviço Social e E'ducação em Saúde Pública, cada uma com suas contribuições especificas e importantes à Saúde pública, o que acontecerá ao e ducador sanitārio e à Educação em Saúde pública tI picos de São Paulo?

A necessidade de responder a essa questão, entre outras razões, levou a Congregação da en tão Faculdade de Higiene e Saúde pública a suspender o curso para reformulação, a 10/07/1961; entre tanto, a reformulação não chegou a realizar-se, ten do em vista as reformas ocorridas em seguida na Universidade de São Paulo, permanecendo suspenso até $\circ$ presente.

A necessidade de um elemento no campo da Educação em Saúde püblica não se fazia sentir apenas em São Paulo. Como consequêncta da tentativa de vārios Estados brasileiros para resolverem seus problemas no campo da Educação em Saúde pública, di ferentes elementos auxiliares foram preparados e co locados em campo. 
Minas Gerais formou, de 1961 a 1968, a s coordenadoras escolares, professoras primárlas ou prē-primárias, com o objetivo de capacitá-las a co ordenar as ações assistenciais-educativas de saúde nas escolas. Durante o periodo compreendido entre 1961 e 1968 foram treinadas 689 coordenadoras esco lares de saúde; 440 em Belo Horizonte e 249 em Jú iz de Fora. Ainda em Minas Gerais, em 1969 foi rea lizado treinamento de supervisores escolares de sa úde pela Escola de Saúde Pública de Belo Horizonte. o objetivo desse treinamento foi preparar pessoal para supervisionar o trabalho das coordenadoras es colares de saúde ${ }^{48}$. O Paraná, atravēs da Escola de Saúde Pública da Secretaria da Saũde, desde 1963 vem oferecendo treinamento para educadores sanitários de nivel médio. O Rio Grande do sul tem tambēm, a través da Escola de Saúde pública da Secretaria da Saúde, treinado educadores sanitários de nível não universitário. Santa Catarina, para poder dar expansão ao Projeto de Saneamento Básico Comunitário, da Secretaria da saúde, treinou em 1972 pessoal po livalente para desenvolver atividades de Educação em Saúde Pública e de saneamento ${ }^{48}$. Embora alguns 
Estados brasileiros tenham resolvido parcialmente seus problemas no campo de recursos humanos para a Educação em Saúde Pública, muitos outros continuam com carência total desses elementos. A falta de re cursos humanos realmente capacitados, ao lado do re conhecimento de que para erradicar, minimizar ou controlar os problemas que impedem a população de alcançar niveis adequados de bem-estar físico, men tal e social, é necessārio prepará-la na área da E ducação em Saúde, contribuiram para a concretização de uma idéia que vinha amadurecendo na Faculdạ de de Saúde Pública da Universidade de são Paulo des de 1952: a criação do Curso de Educação em Saúde Pública na própria Faculdade, à semelhança dos já existentes nos EUA, Japão, Filipinas, India e URSS. Esse curso fol aberto a candidatos portadores de di ploma de curso superior, com priorldade para os oriundos das áreas das ciências humanas, outorgando ao término de um ano acadêmico o diploma de Educador de Saúde Püblica. o curso pode levar ao títu10 de Mestre em Saúde Pública, desde que o candidą to cumpra os necessários créditos dentro de um minimo de 18 meses. 


\section{O EDUCADOR DE SAODE PUBLICA}

O educador de saúde püblica é um profissional com formação acadêmica nas áreas da Educação e da Saúde, que o habilita a desenvolver os as pectos educativos dos programas de saúde. A ele ca be a tarefa de desencadear todo o processo de mudanças inerentes à consecução dos objetivos dos pró gramas de saúde. Sendo, portanto, um agente de mu danças, cuja atuação visa a melhoria da saúde dos individuos e grupos, seu preparo acadêmico inclui conhecimentos sobre:

- "Educação, especialmente os fatores determinantes do comportamento humano;

- Clênclas Soc1a18, para compreender as caracterís t1cas sócio-econômico-culturais das populações;

- Saúde pública, incluindo principios de administração sanitária, saneamento do meio, métodos de controle das doenças, interpretação estatistica, planejamento de programas;

- Administração de serviços de educação em saúde pú 
blica e de educação em saúde na escola;

- metodologia da educação em saúde pública;

- técnicas de investigação aplicadas à educação em saũde püblican 48 .

Além disso, dependendo da agência em que vai atuar, o aluno é orientado no sentido de obter outros conhecimentos básicos em saúde pública como, por exemplo, os relacionados à área de saúde mater no-infantil e nutrição.

"o educador de saúde pública é um especialista que, por seu preparo especial, deve possuir alta competência e capacidade de liderançaque The permita se encarregar de trabalhos de planeja mento e organização, de estudos e investigações na ārea da Educação em Saúde Públican48. E o técnico especializado em métodos e técnicas educativas que favorecem, facilitam e aceleram o processo de mudança de comportamento das pessoas e que auxilia o pessoal de saúde a um melhor desenvolvimento de seu trabalho educativo ${ }^{7}$. Devido a essas caracteristicas, o educador de saúde pública passou a ser ele- 
mento altamente requisitado não só no campo da Saú de Pública, como também no da educação. Isso fez com que, embora sua formação o preparasse especif 1

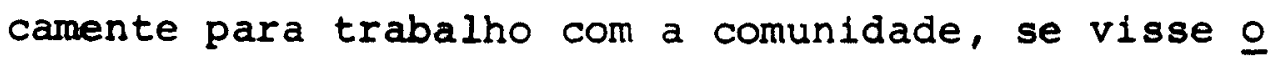
brigado a assumir também o campo da saúde escolar. Percebendo desde logo essa realidade e os problemas que poderiam surgir da não adequação do profís sional às necessidades do campo de trabalho, o Cur so da Faculdade de Saúde Pública, a partir de 1971, vem focalizando também a Educação em Saúde na escọ la, favorecendo a adequação do profissional às necessidades e realidades dos sistemas educacionais brasileiros.

Embora o educador de saúde pública possa atuar tanto em serviços püblicos como em empresas particulares ou agências voluntārias de saúde, no Brasil, segundo KRAUSZ21, ele é mais comumente encontrado nos quadros dos serviços públlcos de nivel federal, estadual ou municipal. A explicação de tal fenōmeno reside, possivelmente, no fato de que os serviços püblicos (principalmente as secretarias de Saúde e Educação), já conhecem o profis- 
sional e, reconhecendo a validade do seu trabalho, tèm se preocupado em formar seu próprio pessoal. Co mo conseqtência, a Faculdade de Saúde püblica tem recebido, anualmente, um grande contingente de alu nos oriundos dos quadros do serviço público de todo o Pais. No momento, a Faculdade de Saúde Pübli ca da Universidade de são Paulo é a única Escolada América Latina ocupada em preparar recursos humanos para a educação em saúde a nível pós-universitário, tanto na área da Educação em Saúde comunitāria como na de saúde na escola. De 1967 a 1975 foram for mados 200 educadores de saúde pública pela Faculda de de Saúde Pública da Universidade de são Paulo, número esse muito aquēm das necessidades do Brasil.

A Educação em Saúde não constitul patrimônio exclusivo do educador de saúde pública, mas pode e deve fazer parte integrante do trabalho dia rio de todos aqueles profissionais que constituem a equipe de saúde. Isto não significa, entretanto, que eles possam substituir o educador de saúde pública. Como afirmam KLEINSCHMIDT \& ZIMAND20, o educador de saúde pública é o elemento que investe 
todo o seu tempo no processo de Educą̧̃o em Saúde. Ele realiza em profundidade, aquilo que outros pro fissionais realizam apenas superficialmente ${ }^{48}$. Tem sido definido como um "conselheiro em saúde, educa dor, estimulador, conciliador e agente catalizador ${ }^{36 n}$. Ele ajuda individuos e grupos a reconhecer, compre ender e se responsabilizar pela solução de problemas de saúde pessoais, da familia e da comunidade. Baseado em fatos levantados por outros técnicos, e le è capaz de interpretar as necessidades de saúde de uma comunidade, os comportamentos de saúde dese jáveis para esse grupo e os serviços de saúde de que dispõe. Ele suplementa de uma maneira organ1zada e continua o trabalho de outros profissionais, tanto da área de saúde comunitária como de saúde es colar, sem entretanto, substitui-los 20 .

A clientela do educador de saúde pública é a própria equipe da qual ele é un dos membros; sua responsabilidade é proporcionar aos demais elementos da equipe (médicos, dentistas, professores), 으 portunidades de aprendizagem, de modo a que possam transformar cada um dos seus contatos com indivi- 
duos ou grupos da comunidade, em uma situação educativa.

Segundo MARCONDES*, "é com ○ homem, não com máquinas e computadores que o educador de saúde püblica trabalha, e portanto, o seu trabalho de ve estar muito mais orientado para o processo do que para a tarefa".

* marcondes, R.S. - Discurso de posse da la. Diretoria da Sociedade dos Educadores de Saúde Públi ca - São Paulo, 1974. 
CAPITULO II

CONCEITUAÇ AO 


\section{CAPITULO II \\ C O N C E I T U A Ç $\AA 0$}

Saúde, assim como educação, parece ter di ferentes significados para diferentes pessoas. Dai seus conceitos variarem no tempo e no espaço ${ }^{32}$. A integração de "saúde" e "educação" no termo "educa ção em saúde" estabelece que saúde implica no conteúdo e educação no processo. o conteúdo de saúde define o que deve ser ensinado sobre saúde e o processo educacional determina como a aprendizagem se realizarál. Sendo Educação em Saúde uma expressão que envolve dois elementos diferentes mas indissociāveis, è importante que se conceitue cada um deles em separado, para posteriormente se chegar ao concelto da expressão total.

Saúde encontra seu melhor sentido no ter mo anglo-saxônico "health", que originalmente sig- 
nifica a condição de estar bem, sadio, ileso. Com - passar do tempo, entretanto, esse sentido originário fol sendo gradativamente modificado, atribuindo-se à saúde um aspecto negativo de libertação de doença ou defeito já estabelecidos. Modernamente, as origens do termo saūde estão sendo redescobertas e sob essa forma è que vem sendo conceituado.

Para JOHNS, SUTTON \& WEBSTERl9, "saũde é a qualidade resultante do funcionamento total do in dividuo no seu meio, que o habilita a alcançar uma vida pessoalmente satisfatória e socialmente útil". A Organização Mundial da Saúde (OMS), em 1946, jā conceituava saúde como um estado de completo bemestar fisico, mental e social e não meramente como ausência de doença ou enfermidade 50 . No documento "Programas de Saúde para o Sistema de Ensino no Brä siln49, saüde é conceituada como "uma qualidade de vida a que o homem aspira e que resulta da realizá ção māxima do seu patrimônio genētico em interação com o melo e através de ações inteligentes". Saúde constitul um dos componentes da vida humana e, devido à sua complexidade, pode ser analisada sob dí 
ferentes enfoques. Assim, ela è uma unidade multí dimensional, envolvendo aspectos físicos, intelectuals, sociais e emocionais do homem. E um proces so dinâmico e não uma condição estática. Saúde dẹ pende não só do que as pessoas sabem, mas principalmente do que fazem; envolve não só conhecimentos adequados, mas tambēm, e principalmente, comportamentos condizentes com esses conhecimentosipor tanto, saúde está condicionada ao comportamento dos individuos.

Etmologicamente, o termo educação originou-se do latim "educatio ou educere", que signifi ca formar, tirar para fora. Por muito tempo, toda via, educação fol um processo que se preocupou a penas com a transmissão de conhecimentos; as neces sidades do educando e a adequação desses conhecimentos à sua realidade social não eram sequer ques tionadas. Hoje a situação é outra. Em uma sociedade de mudança como a em que vivemos, a educação aos poucos está se transformando em um instrumento de aquisição de bens e de "status". Conseqtentemente, o processo educativo preocupa-se presente - 
mente com o educando e com o que ele necessita aprender para poder, integrar-se eficazmente na estrutura social da qual é membro. Como parte integrante do termo Educação em Saũde, a educação pretende auxiliar os indivíduos a alcançarem seus pró prios objetivos de vida. Deve, portanto, oferecer amplas oportunidades de conhecimento que possibili tem e favoreçam condições de opção ao individua Por outro lado, è necessārio que não se confunda Educa ção com informação. Educação envolve motivação, rea ção, interação e mudança ou reforço de comportamen to, enquanto informação consiste no oferecimento e obtenção de fatos. Educação é um processo global, do qual informação è apenas uma parte*.

Educação em Saúde, segundo MEANS, è a cị ência e arte relacionadas com uma vida saudável. Preocupa-se com o comportamento do individuo em in teração com o meio, no que se refere à saúde; é o processo de prover experiências que influenciem fá

* SPILLANE, A. - Some guidelines for health education, (s.n.t.) (mimeografado). 
voravelmente a compreensão, atitudes e práticas de saúde relativas ao indivíduo, familia e comunidade. Educação em Saúde pode ser considerada como ciência aplicada derivada das ciênclas biológicas e com portamentais, com o enfoque necessário para cobrir a lacuna entre as descobertas cientificas no campo da saúde e sua aplicação à vida diária de cada homem $^{32}$.

De acordo com ROBERTS ${ }^{39}$, Educação em Saú de è hoje reconhecida como medida fundamental na pro moção de prāticas individuais e comunitárias de sa úde. Essa abordagem demonstra que a Educação em Sa úde auxilia as comunidades a conscientizarem seus problemas ou necessidades no campo da saúde, a trans ferirem esses problemas para suas vidas particulares, a selecionarem medidas adequadas para sua solução e, finalmente, a adotarem o comportamento ne cessário e mantê-1o. A Educação em Saúde possibilita que a população, por sua própria escolha, chẹ gue à aceitação, adoção e manutenção de práticas de saúde desejáveis e adequadas à realidade social em que vive. E quando isso acontece, essas prāticas 
são integradas aos seus padrões de vida, o que nor malmente não acontece quando são impostas.

Na 12a. Assembléia Anual da Saúde promovida pela $\mathrm{OMS}^{14}$ em Genebra, concluiu-se que Educação em Saúde é a soma de todas aquelas experiências de um individuo, grupo ou comunidade, que influenciam suas atitudes e comportamentos, assim co mo os processos e esforços necessários para produzir essas mudanças. Este conceito focaliza o aspecto de que experiências de natureza positiva ou negativa provocam impacto nos indivíduos, influindo no que cada pessoa, grupo ou comunidade pensa, sente e faz em relação à saúde. A Educação em Saú de preocupa-se com as pessoas e com seu comportamento em saúde. Identifica suas necessidades e pro blemas e busca as soluções viáveis ${ }^{l}$.

Em 1955, o Comitê de Técnicos de Educação em Saúde Pūblica, que pela primeira vez se reú nia como consequência de decisão da Assembléia Mun dial da Saúde, conforme indica BRITO BASTOS6, concluiu que a finalidade da Educação em Saúde públi- 
ca é ajudar os individuos a alcançarem saúde por meio de seus próprios atos e esforços, sendo os se guintes seus principais objetivos:

1. fazer da saúde um valor aceito pela comunidade;

2. equipar os individuos com conhecimentos e habilidades que o ajudem a resolver seus proprios pro blemas de saúde;

3. promover o desenvolvimento dos serviços de saúde.

Em linhas gerais, a grande tarefa da Edü cação em Saūde é favorecer a mudança ou reforço de atitudes e comportamentos dos individuos em relação à sua própria saũde, de seu grupo ou comunidade; estimula-os a perceber seus próprios problemas de saúde e ajuda-os a buscar soluções adequadas para esses problemas. GUILBERT 17 considera que a Educação em Saúde é uma responsabilidade irrecusāvel de todos os serviços oficiais e particulares de saúde, assim como uma função inerente a todos os profissionals que trabalham na área da saúde Pú blica. 
A Educação em Saúde, considerada como um meio eficaz para que os individuos atinjam seus pró prios objetivos, precisa integrar-se no contexto dia rio de suas vidas, sendo necessário para isso fazer-se uso de todos os recursos disponiveis na comunidade. Entre esses recursos destaca-se un de Im portância impar: a escola. A importância da esco la na formação global dos individuos é tão expressiva que a Educação em Saúde, para melhor atender as necessidades específicas dessa instituição, vem cada vez mais desenvolvendo e aperfeiçoando recursos humanos, métodos e materiais que tornem mais $e$ ficaz sua ação, na formação dos escolares. Segun do TURNER ${ }^{4}$, a Organização Educacional Cientifica e Cultural das Nações Unidas (UNESCO) e a Organiza ção Mundial da Saúde (OMS) reconhecem a Educação em Saúde na escola como importante parte da educação geral e um meio vital de promoção da saúde. A Edú cação em Saúde na escola proporciona oportunidades excelentes para se formar nos individuos as atitudes e comportamentos corretos em relação a problemas de saūde 35 . 
A escola tem funcionado, desde há multo tempo, como intérprete das descobertas cientificas para o püblico. Ela tem-se constituío em instrumento pelo qual os alunos compreendem os avangos do mundo e o significado da cultura. E através da educação que se combinam conhecimento e inteligência visando ao desenvolvimento dos meios pelos quais o homem controla seu ambiente e assegura sua subsistência. Sem esses meios o homem não pode sobreviver, afirma OBERTEUFFER 34 .

De acordo ainda com OBERTEUFFER, o objetivo final da Educação em Saúde püblica, seja em termos de escola ou de comunidade em geral, é libe rar as forças potenciais do homem, energias e virtudes, de modo que sua ação se torne amplamente sạ tisfatória e humanamente construtiva em saúde. Além disso, deseja influenciar favoravelmente a vida das populações e pretende que os conhecimentos de Jenner, Pasteur, Koch e tantos outros ajudem os hamens de hoje a ter uma vida melhor ${ }^{34}$. Dessa maneira, as descobertas cientificas são importantes e válidas, à medida em que são utilizadas para melhorar a vi- 
da de todos os homens. No terreno da saúde o comportamento è mais importante do que qualquer conhe cimento ou atitude. A idéia é impotente, se desli gada da ação.

Dentre todas as instituições de uma comu nidade que trabalham com o público, a escola é tal vez a única que conta diariamente com uma clientela permanente. A ela cabe a responsabllidade de con tribuir para a formação dos indivíduos, enriquecen do-os com conhecimentos e experiências adequadas pa ra a sua realização como membros útels de uma sociedade. Apesar disso, a escola não pode e nem de ve se propor sozinha a promover, proteger e se pos sivel recuperar integralmente a saúde da criança. Pode e deve, entretanto, ao lado da familia e da co munidade, contribuir para que seus alunos alcancem a saúde. A posição que a Educação em Saúde deve 으 cupar na escola vem sendo defendida desde há muito tempo por educadores e higienistas. Já por volta de 1931, afirmava-se que devido à complexidade das diretrizes e sistemas da Educação, mesmo variando os objetivos morais ou sociais da escola, não devem 
variar aqueles referentes à formação de um individuo sadio. Por outro lado, nenhuma sociedade civiliza da pode descurar dos problemas de saúde e nenhuma escola verdadeira pode desprezar o seu valor na cons trução e defesa da vida humana ${ }^{46}$. De acordo com TURNER47 a escola fornece a formação em saúde para seus alunos e gradualmente prepara-os para a vi da familiar e de cidadãos. A Educação em saúde na escola não visa a manipulação do comportamento das crlanças desvinculada dos conhecimentos de saúde; ela pretende ajudar cada aluno a compreender a si próprio como um ser físico, mental e social a entender problemas de saúde, analisar o que pode ser feito e quais os benefícios que serão obtidos.

Reportando ao concelto mencionado por DERRYBERRY 24 , encontra-se que a Educação em Saúde supōe a existência de experiências e não apenas transmissão de conhecimentos. Assim sendo, a Educação em Saúde na escola significa a aquisição de conhecimentos e a formação de atitudes e valores que levem o escolar a um comportamento que reverta em beneflcio de sua própria saúde e da saúde dos ọ tros. 
A fim de que a saúde ultrapasse o campo do conhecimento para transformar-se em comportamen to, é preciso que se torne um fator airetivo, estạ belecido no contexto diário da vida dos escolares. A Educação em Saúde na escola oferece aos a lu nos meios para que vivam melhor; ajuda-os a conhecer a problemática da saúde de seu país, e em partıcular de sua comunidade, a preocupar-se com esses proble mas e a procurar soluções adequadas para os mesmos.

No Brasil, Saúde passou a fazer parte obrigatória do currículo pleno escolar do 18 e 28 graus a partir da promulgação da Lei Federal 5.6922, que veio reforçar e reconher sua importância para se atingir os principais objetivos da Educação: au to realização, qualificação para o trabalho, prepa ro para o exercício consciente da cidadania e capa citação para o estabelecimento de relações interpessoais5. Entretanto, o texto da referida lei não esclarece como deveria ser desenvolvida essa nova disciplina. Fo1 só em 1974 que o Conselho Federal de Educação emitiu o Parecer n8 2.264, que definiu saúde no currículo escolar como Educação em Saúde, 
cabendo-lhe a tarefa de desenvolver conhecimentos cientificos, atitudes e comportamentos relativos à saúde ${ }^{15}$. Complementando as considerações desse Pa recer, durante a IV Jornada Brasileira de Estudos de Educação em Saúde, em 1975, realizada em BrasIlia, fol enfatizada a necessidade de que a Educação em Saúde na escola deve se alicerçar nas experiênclas e condições de vida das populações das àreas onde ela se desenvolve.

Embora a responsabilidade pela saúde do escolar seja basicamente dos pais e de modo algum possa ou deve ser-lhes retirada, durante 0 tempo em que as crianças estão na escola, esta substitui os pais. Desta maneira, entre outras responsabilidades, a escola assume as referentes à saúde e bem-es tar de seus alunos. Para que esse aspecto da esco la funcione adequadamente, é necessārio que a área da saúde seja trabalhada com fundamento em um plano, cujos objetivos básicos são:

- contribuir para proteção e promoção da saúde do escolar, proporcionando um ambiente físico e emo cional adequado ao seu crescimento e desenvolvi- 
mento, ajudando-o a compreender a importancia dos exames de saúde periódicos, estimulando-o a utilizar os recursos da comunldade, concorrendo para prevenção e controle das doenças transmissiveis;

- desenvolver um currículo orientado no sentido de atender as necessidades e interesses do escolar, proporcionando-lhe experiências de aprendizagem que o habilitem a aplicar as descobertas cientificas em beneflcio de sua saúde;

- levar o escolar a compreender a necessidade da sua participação para o equacionamento dos problemas de saúde pessoais, de sua família e de sua comunidade ${ }^{29}$.

Para que os programas de saúde escolar al cancem com êxito seus objetivos, a Educação em Sậ de deve desenvolver-se através de quatro diferentes dimensões, abrangendo cada uma delas necessidâ des específicas da saúde da criança em idade escolar e pré-escolar. Essas quatro dimensões, ambien te físico e emocional da escola, serviços de saúde, ensino da saúde e Integração lar-escola-comuní dade, abrangem todos os aspectos do universo escolar, contribuindo cada uma delas para que se con- 
cretize o processo da Educação em Saúde. Assim, se gundo afirma MARCONDES29, a dimensão ambiente esco lar implica em oferecer às crianças condições físi cas adequadas ao seu desenvolvimento integral, bem como condizentes com o ensino da saüde que vem recebendo. Do mesmo modo, o relacionamento dos professores entre si e com os alunos constitui parte importante do ambiente emocional que contribui para a formação global da criança. Serviços de saúde têm por objetivo desenvolver atividades ligadas à prorioção, proteção e recuperação da saúde do escolar e que sejam condizentes com o ensino da saúde desenvolvido na escola. O ensino da saúde preocupa-se em oferecer informaçōes que possam ser útels ao escolar na formação de comportamentos adequados à sua saúde e à de sua famillia, assim como em interpretar para ele os conhecimentos e as descobertas cientificas, de modo a que possam ser aplicados em sua vida diāria. Finalmente, a dimensão lar-escola-comunidade compreende todas as atividades que contribuem para $\circ$ desenvolvimento de relações de cooperação entre 
a escola, a familia e a comunidade; preocapa-se prin cipalmente em fazer com que a escola seja realmente um centro, aberto à comunidade, bem como em dar aos pais responsabilidade pelas atividades que desenvolve e, em última anālise, pela formação que seus filhos estão ai recebendo. Qualquer que seja - aspecto desenvolvido pelo programa de saúde, a ên fase recairá fatalmente em uma dessas dimensões, de vendo contar com a Educação como instrumento indis pensāvel para a sua consecução.

A promoção da saúde, como se pode perceber, constitul uma tarefa extremamente complexa, que ultrapassa as possibilidades das ciências médicas apenas. E evidente a necessidade de múltiplos pro fissionais de saúde capacitados para atuar em dife rentes niveis, de acordo com sua formação básica e com o papel que lhes cabe desenvolver dentroda pro gramáção de saúde ${ }^{4}$. Entre esses profissionais destaca-se o especialista em Educação em Saúde Pública, particularmente importante para o êxito dos pro gramas de saúde desenvolvidos tanto na comunidade como na escola. Este trabalho, focaliza o educador de saúde pública atuando no sistema escolar. 
A SECRETARIA MUNICIPAL DE EDUCAÇAO DO MUNICIPIO DE SAO PAULO 


\section{CAPITULO III}

\section{A SECRETARIA MUNICIPAL DE EDUCAÇÃO DO MUNICIPIO DE SAO PAULO}

A Secretaria Municipal de Educação (SME) da Prefeitura do Municipio de são Paulo, foi criada em 194713, sendo responsāvel ao lado da secreta ria dos Negócios da Educação do Estado de São Pau10, pelo ensino de 18 grau. Compete-lhe planejar, orientar, superintender e executar as atividades per tinentes à rede de escolas municipais, de acordo com a Lei Municipal n8 $7.693^{24}$ e a Lei Federal 5.69222, que define as diretrizes nacionais de educação. Com a promulgação da Lei Municipal no $7.037^{23}$, e recentemente da Lei no $8.204^{25}$, a SME passou a ter a se guinte estrutura:

I - Gabinete do Secretārio (Assessorias e Expedi ente);

II - Departamento Municipal de Ensino (EM); 
III - Departamento de Educação Infantil (ED);

IV - Departamento de Assistência Escolar (EA);

A clientela da SME inclui pré-escolares e escolares, abrangendo uma faixa etária que se es tende dos 3 aos 14 anos.

1. ASPECTOS RELATIVOS A POPULAÇAO ESCOLAR DO MUNICIPIO DE SÃo PAULO

Como a grande maioria das escolas se situa na região periférica da cidade, a população que demanda essas unidades se origina das classes socí ais menos favorecidas do município. Esse fatar, por si só, tem implicações no desenvolvimento sóciocultural e, consequlentemente, na saúde de seus alu nos.

Estudos realizados em 1973 pela $\operatorname{SME}^{33}, \mathrm{v} \underline{\underline{i}}$ sando ao diagnóstico da situação na rede municipal de ensino, vieram constatar que a repetência escolar constitui um de seus principais problemas, ocorrendo acentuadamente nas primeiras séries do 18 
grau, decrescendo gradativamente até às quartas sê ries, recrudescendo novamente nas quintas, para di minuir nas séries subsequlentes. Como causas de tal fenômeno foram apontadas duas variäveis de orıgem sōcio-econômica :

- problemas relativos à saüde do escolar, principal mente no que se refere à alimentação;

- problemas decorrentes da carência cultural do meio em que vive o escolar.

No que se refere à primeira variável, è frequlente afirmar-se que, deficiência alimentar e rendimento escolar mantêm relação de causa e efeito. GIULIANELLI, citado por ROSENBURG42, afirma que - escolar brasileiro apresenta estado precário de nutrição devido à alimentação inadequada, ao desco nhecimento da educação alimentar e baixa capacidade econômica dos pais ou responsáveis. Estudos rea Iizados por GIULIANELLI, no Brasil, revelaram que:

- "grande porcentagem dos escolares brasileiros não atingia niveis normals de crescimento e desenvol vimento fisico e mental; 
- elevado número de crianças chegava à escola em completo jejum;

- os alunos desmalavam de fome durante as atividades escolares;

- por sua alimentação insuficiente, muitos escolares eram desatentos e demonstravam sono durante as aulas;

- as crianças sub-nutridas, além de se fatigarem com facilidade e de não possuirem resistência às enfermidades, não retinham com facilidade as 11çōes;

- Indice de frequência nas escolas que serviamme renda era multo mais elevado 42 .

Por outro lado, REAO ${ }^{38}$ comenta que a fome pode alterar o aprendizado, observando que multo do que se diz sobre fome e comportamento na sala de aú la é, fruto de opiniões subjetivas de pals e profes sores. Entretanto, somadas todas, elas indicam que os programas de alimentação escolar diminuem a sonolència, a apatia e determinam melhoria das atitú des, atenção e rendimento escolares. 
Para contornar o problema da deficiência alimentar dos alunos, as unidades da rede municipal de ensino contam com um sub-programa de merenda escolar, que visa a suplementar as necessidades proteico-calōricas diārias das crianças matriculadas. Entretanto, como afirma ROSENBURG42, "o maior ou menor sucesso dos programas alimentares desenvolvidos nas unidades da Secretaria de Educação es tará sempre condicionado à participação de cada unidade no que diz respeito ao desenvolvimento para lelo de programas de educação alimentar. Não basta que se dê comida à criança, mas é fundamental en sinā-la a bem se alimentar".

Afirma o mesmo autor que, "embora não apresentando a mesma gravidade constatada nos grupos mais jovens, a alta prevalência da MPC* entre os.escolares, justifica plenamente a implantação dos programas de assistência alimentar especificamente dirigidos a esse grupo populacional, especialmente se o fornecimento de alimentos pelas escolas for

* MPC = má nutrição proteico-calörica. 
planejado como parte integrante de um programa mais amplo de educação alimentar. Se atentarmos para a importância representada pelo fator educação na etiologia da MPC, não teremos dúvida em classificar como prioritárias todas as atividades de assistência alimentar, dirigidas ao escolar, jà que è durante esta fase da vida que cada individuo apresen ta as melhores condições para incorporação de novos conhecimentos e de novos häbitos alimentares"42. Nestas afırmaçōes transparece claramente a impor tância do componente educatıvo dos programas de alimentação escolar e que pode, sem dúvida, ser extrapolada para o restante do programa de saúde escolar.

No que tange à variável carência cultural, estudos realizados pela SME indicam, camo prin cipal causa, a localização da maioria das unidades escolares do municipio em áreas onde os niveis socio-econômicos e culturals da população são desfavoráveis. Afirmam os técnicos da SME que a malorıa das crianças dessas āreas não apresentam as condições necessārias para acompanharem satisfatoriamen 
te o processo de aprendizagem formal do $18 \mathrm{grau}^{3}{ }^{3}$. Com base nesse pressuposto, O EA realizou uma pesquisa visando a estabelecer um relacionamento entre a idade mental e a idade cronológica das crian ças de la. série do 19 grau da rede municipal de en sino. Resultados dessa pesquisa revelaram que, em médla, essas crianças tèm 5,2 anos de idade mental, "versus" uma idade cronológica de, no minimo 7 anos, não apresentando, portanto, o amadurecimento neces sário para participarem com èxito do processo de $\underline{a}$ prendizagem ${ }^{3} 3$.

A partir da identificação dos aspectos cau sais da repetência escolar, foram estabelecidas al gumas medidas para, se não resolver, ao menos mini mizar seus efeitos negativos. Nesse sentido, ao la do das atividades já existentes de merenda escolar, prevenção de tuberculose e atendimento odonto lógico, foi proposta maior cobertura e concentração da atividade de assistência médica, assim co mo a implantação da atividade de oftalmologia sanitāria escolar. Essa programação visa a prevenção de agravos à saúde e/ou a recuperação da sạ 
úde dos alunos, tendo em vista seu aproveltamento escolar. Por outro lado, na tentativa de combater os problemas do despreparo da criança que ingressa na la. sẻrie do 18 grau, foi implantado um projeto -p1loto em uma unidade da rede, ldealizado pelo en tão diretor do EA, Dr. Cornēlio Pedroso Rosenburg, com o objetivo de contribuir para o desenvolvimento adequado da motricidade e do código de linguagem aumentando, assim, as possibilidades de êxito da criança ao ingressar na escola. Ao lado desse atendimento pedagógico, a criança tinha acesso, tam bém, ao atendimento médico, odontológico e alimentar, programados para os escolares.

o êxito de tal projeto levou à sua amplia ção. Hoje, sob a denominação de PLANEDI (Plano de Educação Infantil), funciona em cerca de 100 unida des da SME.

Entretanto, apesar das medidas tomadas por parte da SME, a retenção dos alunos permanece ao redor de 408 nas primeiras séries e 308 nas quil tas séries, provando que as providências tomadas 
são insuficientes para alcançar o efeito desejado ${ }^{33}$.

Tal situação levanta a hipótese de que a Introdução da Educação em Saúde Pública em todos os programas que tenham por objetivo a saúde do escolar, poderá contribuir para a solução desse proble ma. Se a saúde do escolar é elemento chave para o êxito do processo de aprendizagem, a Educação em Saúde deveria, como já preconiza a Lei $5.692^{22,44}$ e - Parecer n\& 2.264 do Conselho Federal de Educaçãd5, fazer parte do currículo pleno escolar das escolas de 18 e 28 graus, contribuindo assim com a parte que the cabe para o sucesso do processo ensino-aprendizagem .

2. A EDUCAÇÃO EM SAODE NA SECRETARIA MUNICIPAL DE EDUCAÇÃO

A Educação em Saúde na escola deve ser considerada como parte do processo educativo global, cujo objetivo ültimo è a criança. Recomendase que seja programada em conjunto com as demais dis ciplinas do curriculo, de modo a fazer parte do con 
texto diārio da vida da criança na escola. Para que isso se concretize è necessário que cubra quatro à reas: ensino da saúde, serviços de saúde, ambiente escolar (físico e emocional) e integração larescola-comunidade 2 .

\section{ENSINO DA SADDE}

oficialmente, Educação em Saúde, como jã fol mencionado, deveria fazer parte do arriculo ple no escolar das Escolas Municipals de 18 grau; sabe-se, no entanto, que a maioria, senão a totalida de das escolas, permanece omissa nesse sentido. Se gundo CONNER 10 , nos EUA, onde há a mesma problemática em um número considerável de escolas, deve-se esta situação às seguintes razões:

- falta de reconhecimento, por parte do público em geral, da importância do papel da escola no desen volvimento de atitudes e comportamentos adequados em relação à saúde;

- falta de entrosamento entre as agèncias de saúde e de educação da comunidade, de modo que estas pos sam contar com os recursos humanos emateriais di $\underline{s}$ poníveis daquelas; 
- inadequado preparo dos professores na área da Educação em Saúde;

- tendência em relegar Educação em Saúde a uma posição inferior à conferida a disciplinas tais co mo ciências e matemática.

Afirma CONNER ${ }^{10}$ que, em muitos casos, a Educação em Saúde faz parte do programa de Educação Física, sendo ensinada por um professor com inadequado ou nenhum preparo em Educação em Saúde e que muitas vezes não tem interesse pela matēria.

o que ocorre na SME, provavelmente pelos mesmos motivos citados por CONNER, é que o desenvolvimento da área da saúde fica na dependência do professor, podendo este decidir se deve ou não incluí-la em sua programação. Note-se que, ainda ho je, os cursos básicos de formação do professor de 18 grau (18 e 29 níveis) e mesmo os cursos superio res de Pedagogia e Biologia não contêm nos seus cur rículos, o conteúdo programātico especifico de saụ de que capacite os professores a planejarem, desen volverem e avaliarem a disciplina saúde, da mesma 
maneira como o fazem com as demals disciplinas do programa escolar. Ao fato de que o professor não possui formação suficiente na ārea de saúde, situa ção que mereceu estudo detalhado por MARCONDES ${ }^{30}$, junta-se a dificuldade de encontrar bibliografia $\underline{a}$ dequada sobre o assunto, falta de orientação e supervisão pedagógica nessa área e a inexistência de um programa definido constituído não apenas de tópicos esparsos sobre saūde, mas de assuntos organi zados em uma linha de aprofundamento seqtencial, de modo a formar um todo harmônico. E preciso que a criança receba informaçōes, ao mesmo tempo em que tem oportunidade de vivenciā-las na própria escola e que tais informações e experiências constituam, ao final de seu curso de 18 grau, os elementos minimos necessários à sua atuação adequada como futụ ro cidadão. Provavelmente, a criança não aplicará em casa tudo o que vivencia na escola, em conseqưência de variáveis diversas e de intensidade con siderável, mas é de se esperar que quando adulta, com poder de opção e livre escolha, recorde os ensinamentos recebidos na escola, pondo-os em prática. No que se refere à área de ensino da saúde, es 
ta è a situação vigente até o momento nas unidades da SME.

\section{SERVIÇOS DE SAUDE}

Das dimensões a serem cobertas pelo programa de Educação em Saúde na escola, é esta, real mente, a única que vem, através do EA, recebendo um tratamento mais cientifico. Suas atividades são ba seadas em necessidades reais dos escolares e desen cadeadas, dentro das possibilidades de recursos hü manos, financeiros e materiais vigentes, visando a minimização dessas necessidades.

Os escolares do Município de São Paulo são alvo da seguinte programação 45 :

- atendimento médico-sanitário;

- atendimento odontológico;

- atendimento alimentar.

Cabe esclarecer que o atendimento médicosanitārlo significa:

- inspeção médica escolar para fins de educação fí sica, para alunos de 5a. a 8a. séries; 
- inspeção médica escolar do maior número possivel de alunos de la. a 4 a. séries e de pré-escolares, visando detectar desvios e deficièncias de ordem fisica, que possam interferir no rendimento esco lar dos alunos;

- prevenção contra a tuberculose, através da vacinação BCG intra-dérmico em alunos de la. a $4 \mathrm{a}$. séries;

- assistência of talmológica para aqueles alunos que, após triagem pelo professor da classe, demonstrem deficiência de visão;

- assistência psicológica para aqueles alunos que apresentam problemas de ordem psicológica, visan do sua recuperação.

Entretanto, para que cada uma dessas ati vidades atinja seus objetivos não apenas momentàneamente, mas a longo prazo, é necessārio que se ba seiem em um componente educativo que the garanta u ma participação ativa por parte da clientela a quem se dirigem.

No caso dos serviços oferecidos para os escolares da rede municipal de ensino, isso aconte ce apenas com as atividades de prevenção da tu- 
berculose e de oftalmologia sanitäria escolar. Nes se cạso, técnicos do EA, através de entrevistas, 은 rientam os diretores das unidades de ensino quanto ao significado da vacinação pelo BCG intra-dérmico ou do exame oftalmológico para a proteção da saúde dos alunos, à época e modo com que essas ações de saúde se desenvolverão e ao papel que cabe à escola no preparo dos alunos e familiares, visando a sua compreensão do valor dos serviços de saúde ofe recidos. Nestas circunstâncias, aqui também a con cretização do processo educativo fica na dependência da boa vontade e interesse dos diretores das es colas que, como afirma CONNERlo, nem sempre estão despertos para o importante papel a ser desempenha do por elas no que se refere à Educação em Saúde.

Essa estratégia de ação em que não se prẹ vê, ou se prevê de maneira muito tênue, o desenvol vimento sistemático do conteúdo educativo do programa de serviços de saúde, pode provavelmente anu彑 lar ou minimizar de muito os resultados desejados: que a criança, ao mesmo tempo em que goza dos serviços de saúde, compreenda sua importância e bene- 
flclos que acarretam para sua saúde e, mais tarde, já fora da escola, através de comportamentos positivos em relação à sua saúde e de sua família, com preenda a problemática que envolve o setor saúde.

\section{AMBIENTE ESCOLAR}

Esta dimensão do programa de Educação em Saúde na escola diz respeito à análise do ambiente físico e emocional das escolas. No que se refere ao ambiente físico, cabe às autoridades governamen tais a responsabilidade de oferecer um ambiente es colar no qual as crianças possam trabalhar segura e efetivamente.

MARCONDES e colaboradores ${ }^{26}$ afirmam que con diçōes desfavoráveis do prédio escolar como, inade quação do edifício, da sala de aula, das carteiras e instalações sanitárias, podem contribuir para $\circ$ fracasso escolar. Esta afirmação reforça o ponto de vista de vários autores de que 0 ambiente $f \underline{I}$ sico, podendo influir no rendimento escolar, deveria receber um tratamento prioritário por parte das 
autorldades responsáveis $5,34,47$.

As unidades de ensino da rede municipal são construções novas, seguindo, em sua grande maio ria, um modelo padrão, passível de discussão, quan do analisado à luz da moderna tecnologia que rege a construção de escolas. Cabe aqui mencionar que, embora a SME disponha de um Departamento de Assistência Escolar, cuja atuação se prende à promoção, proteção e recuperação da saúde dos escolares, nun ca the fol solicitado assessorar o grupo responsável pelas construçōes escolares na elaboração de plantas físicas, com vistas à promoção e proteção da saúde dos alunos. Nessas circunstâncias, embora as unidades da SME funcionem em prédios próprios, especialmente construidos para sua função educativa, apresentam falhas decorrentes de:

- má, localização geográfica;

- insolação, ventilação e iluminação inadequadas;

- má distribuição e localização das instalações sa nitárias;

- nümero insuficiente de bebedouros;

- inexistência de refeitório;

- inexistência de chuveiros;

- caixas d'āgua inadequadamente localizadas. 
Representam estes alguns pontos criticos do ambiente físico das escolas municipais, mas que poderiam, perfeitamente, ser previstos e adequadamente planejados, desde que o ōrgão responsãvel pe las construções escolares buscasse a assessoria de que necessita. Afora isso, outro problema a consi derar diz respeito à limpeza e higiene dos prédios, que varia de acordo com a direção da escola, não hạ vendo nenhum tipo de controle sistemático. O maior problema, via de regra, prende-se à manutenção e limpeza das instaçōes sanitárias de uso dos alunos. Não há controle sobre a saúde do pessoal da escola, existindo apenas uma supervisão quanto à higiene pessoal dos individuos que manipulam os alimentos.

0 ambiente emocional, tanto quanto 0 ambiente fisico da escola, influi no desenvolvimento normal das crianças, contribuindo para a formação de personalidades sadias.

A escola não pode prover experiências que favoreçam o desenvolvimento emocional desejável dos alunos, se for dirigida por professores e diretor 
emocionalmente desajustados. BROWNEL $L^{5}$ afirma que, apesar do ambiente emocional sofrer a influência de todos os elementos que direta ou indiretamente atu am na escola, são os professores que representam o fator de maior influência na atmosfera emocional e social da classe.

Tendo conhecimento de que o relacionamen to humano constitui a fonte de grande parte dos pro blemas a serem enfrentados nas escolas e sabendo da gravidade que esses problemas podem assumir, se não resolvidos a tempo e adequadamente, o EA iniciou re centemente um projeto-piloto em duas escolas da re $\mathrm{de}^{45}$. Esse projeto visa a analisar os problemas de relacionamento humano originados na familia ou na escola e que muitas vezes interferem no rendimento escolar. A análise dos problemas é feita em conjunto por um psicólogo, pais e professores, atravēs de discussões de grupo. Esse processo analítí co prossegue até esgotar todos os problemas coloca dos pelo grupo, quando sugerem-se métodos para pre venir, contornar ou solucionar esses problemas, sem pre que possivel sem a intervenção do psiquiatra ou psicólogo. 


\section{INTEGRAÇÃO LAR-ESCOLA-COMUNIDADE}

Das quatro dimensões apresentadas, a inte gração lar-escola-comunidade representa, sem dúvida, a área mais crítica, não sendo compreendida ou, muitas vezes, aceita nem por administradores escolares, nem pela própria comunidade. Como afirma RYAN43, limitações de dinheiro, tempo, pessoal, alēm de variáveis outras, levam as agências da comul nidade a colocarem em posição secundária a necessí dade de uma ação cooperativa entre elas e a escola. Contudo, a formação de conhecimentos, atitudes e prāticas em relação à saúde não depende unicamente dos pais e professores, mas também de médicos, den tistas e demais pessoal da equipe de saúde, assim como de membros de outros grupos comunitários. Se gundo RYAN ${ }^{4}$,"atitudes relacionadas à saúde não mudam ou se desenvolvem da noite para o dia; elas cres cem enquanto nós crescemos".

Apesar das dificuldades de se desenvolver um programa de organização comunitāria visando 
- envolvimento dos grupos locais nas atividades do programa escolar, a SME conta já com duas iniciati vas. A primeira diz respeito ao envolvimento de mães no programa de educação infantil (PLANEDI), $\infty$ perando estas com a professora nas atividades peda gógicas e no preparo e distribuição da merenda e limpeza do local, onde essa merenda é fornecida. A segunda iniciativa se refere à formação de grupos de pais nas escolas, coordenados por um elemento do EA, onde se discutem assuntos levantados pelos pró prios participantes, no que se refere aos aspectos que podem influir no processo de ensino-aprendizagem. Participa do grupo, também, um elemento da própria escola, responsável pela continuidadedo pro jeto e que deve estimular a formação de novos grupos de discussão, atē que toda comunidade escolar seja atingida. Na verdade, a maior dificuldade no desenvolvimento desse projeto diz respeito à adesão desse elemento da escola, sem a qual, o trabalho perde a razão de ser.

A avaliação desse projeto, após um a no de execução, veio mostrar que, apesar das dificul- 
dades encontradas, torna-se necessário que ele seja continuado e ampliado a toda a rede de ensino. Ele permite que os responsáveis a nivel local e ch tral pelas escolas da SME se utilizem do "feed-back" fornecido pelos pais durante as reuniões, fazendo dele um instrumento de avaliação de sua própria atuação.

Esta é, no momento a situação da Educação em Saúde na SME, ārea de reconhecida Importância que, entretanto, não vem recebendo o tratamento necessário para um adequado desenvolvimento, sen do mesmo, como afirma $\mathrm{RYAN}^{43}$, relegada a uma posição secundāria em relação a outras prioridades. 
O EDUCADOR DE SAODE POBLICA NA SECRETARIA MUNICIPAL DE EDUCAÇAO 


\author{
CAPITULO IV \\ O EDUCADOR DE SAODE POBLICA \\ NA SECRETARIA MUNICIPAL DE EDUCAÇAO
}

Na Secretaria Municipal de Educação(SME), como acontece em inümeras organizações voltadas pa ra o ensino, a saúde é, possivelmente, o aspecto mais negligenciado do programa escolar*. No capitulo anterior foram apontados alguns fatores responsāveis por essa situação.

A principal função do educador de saúde pública, portanto, será a de colaborar com os demals técnicos visando a integração da educação aos prógramas que pretendem solucionar ou minimizar os problemas de saúde que afetam a capacidade de apren dizagem dos escolares.

* ClIfTON, B. - Educação em Saūde na escola: uma e nunciaçäo de necessidades. (s.n.t.) (mimeografado). 
A atuação do educador de saúde püblica na SME deverá ter como ponto de partida o programa de saúde escolar, tendo em vista as quatro dimensões do programa de Educação em Saúde na escola: ensino da saúde, serviços de saúde, ambiente escolar e in tegração lar-escola-comunidade 29 . Compete-lhe, como agente de mudanças, colaborar para transformar a si tuação vigente na SME no que se refere à área de sá úde, assumindo a sua parte no processo de planejamento da programação de saúde nas escolas da rede de ensino.

\section{ENSINO DA SAUDE}

Até o presente, o programa de ensino da saúde a ser desenvolvido pelas unidades de 18 grau da SME tem sido elaborado por professores da área de ciências físicas e bilógicas, cuja formação bãsica não é especifica na área da saúde. Como resultado, o programa de saúde vem recebendo um enfoque totalmente voltado para ciênclas; enfatiza-se muito mais a doença do que a saúde, valorizando-se 
continuamente as situações de agravos à saúde.

Cabe ao educador de saúde pública, tendo em vista sua formação nas āreas de Educação e Saúde, planejar o programa de ensino da saúde das escolas, de modo a atender às necessidades especificas de sua clientela; todavia, essa è uma tarefa que não deve executar sozinho, mas conjuntamente com outros elementos responsáveis pelo planejamento das demais áreas do currículo escolar. E ainda sua res ponsabilidade adequar e entrosar o programa de saú de com o programa mais amplo de saúde da comunidade, assim como preocupar-se com que o ensino da sạ úde não se realize apenas a nível de sala de aula, mas abranja todas as oportunidades de aprendizagem oferecidas pelos diferentes aspectos da vida escolar.

Estudo realizado pelo EA, entre professo res da rede municipal de ensino, veio demonstrar que 92,08 consideram muito importante a inclusão obrigatōria da Educação em Saúde nas atividades escolạ res $^{3}$. Um outro estudo realizado no Brasil ${ }^{37}$, abran gendo 3.000 pais, cujo objetivo era conhecer que 
assuntos julgavam importantes incluir no curriculo escolar, revelou que o tema "cuidados com a saúde" só fol suplantado por leitura, escrita e matemática. Os dados finais dessa pesquisa em porcentagem foram os seguintes:

- leitura 98,9

- escrita 98,7

- matemātica 98,6

- culdados com a saúde 81,4

- trabalho doméstico 70,0

- geografia 58,0

- rellgião 54,6

- educação física 42,3

- horticultura 33,3

- ciências naturais 32,0

- histōria 30,0

- trabalhos manuais ................ 30,0

- educação artística ............... 30,0

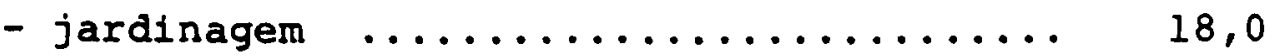

- canto e música .................. 16,0

Os resultados desses estudos definem a posição de professores e pais, revelando sua preocupação com a saūde do escolar e considerando importante sua inclusão no elenco de disciplinas que constituem o currículo escolar de 19 grau. Entre- 
tanto, a preocupação dos pais e professores pela sa ũde do escolar demonstrada nesses dois estudos parece ser meramente intencional, uma vez que nenhuma ação foi desenvolvida, nem qualquer pressão exercida sobre as autoridades competentes, no senti do de que saúde passasse a fazer parte real da pró gramação global das escolas. Possivelmente, os re sultados revelados por esses estudos desencadeariam um tipo diferente de reação se o educador de saúde pública estivesse presente. Conhecedor das ciências do comportamento, teria condições de levar es sa população de pais e professores do nível de pas sividade em que permaneceram a um estágio mais com plexo de ação consciente. Possivelmente, o despre paro dos professores na área de saúde, a ausência de interesse das autoridades pelo assunto, a falta de interesse real da comunidade pelo que se passa na escola aliada à ausência de um elemento catalizador, capaz de desencadear ações desejáveis, tenham contribuído para que a situação vigente não se altere.

De suma importância na dimensão ensino da 
saúde é o treinamento do pessoal docente e dos ele mentos encarregados da orientação e supervisão pedagógica. Será infrutífero todo o trabalho do edu cador de saúde pública em planejar um programa de saúde desde os conteúdos básicos por série, até os instrumentos de avaliação, se ele não se preocupar em envolver os professores, bem como os demais téc nicos,em um treinamento que os habilite a por em prática esse programa de saúde.

o professor precisa ser orientado quanto à sua importância como elemento chave no programa de Educação em Saúde na escola. E possivel desenvolver esse programa prescindindo da participação de vários profissionais, mas é impossivel fazê-10 sem contar com a colaboração do professor. Ele pre cisa saber como aproveitar todo e qualquer acontecimento do dia escolar para ensinar saúde aos seus alunos; precisa conhecer e utilizar os recursos da comunidade para o desenvolvimento do programa de $\underline{E}$ ducação em Saúde na escola; precisa ter consciêncla de que é na escola que a criança tem as melhores oportunidades de ser orientada no que se refe- 
re à saúde; precisa ter presente que os alunos das escolas municipais da SME são crianças multicarenciadas e que o professor, muito mais do que os pais, tem condições de ajudá-las a superar suas dificuldades e deficiências. O esclarecimento do professor quanto a estas e outras situações que envolvem a realidade da população escolar é de responsabili dade do educador de saúde pública.

Torna-se necessário ressaltar que ainda no âmbito do ensino da saúde, compete ao educador de saúde pública um terceiro e não menos importante nivel de atuação, isto é, o de despertar o inte resse dos técnicos e autoridades da SME para a con tribuição do fator saúde na consecução dos objetivos educacionais. Esta é, provavelmente, a tarefa mais importante do educador de saúde pública, pois sua concretização implica diretamente no maior ou menor sucesso de toda a sua ação na dimensão ensino da saúde.

Na SME os serviços de saúde têm o objetí 
vo de promover, proteger e recuperar a saúde dos a lunos. Não se pretende com isso que a escola ocupe o lugar da família no que se refere à saúde das crianças, mas que colabore com ela para que, através de uma ação conjunta, se promova o bermestar do aluno.

A contribuıçào que o educador de saúde pụ blica pode oferecer nesta dımensão relaciona-se com - desenvolvimento do componente educativo desses ser viços. Mencionou-se, anteriormente, que os serviços de saúde oferecidos aos alunos da rede municipal de ensino não têm oferecido efeitos sensiveis sobre o aproveitamento escolar. Na verdade, a comparação entre os nỉveis de repetência de 1973 a 1975 revela que praticamente estes não se alteraram, permanecendo ao redor de $40 \%$ nas primeiras sērles e $30 \%$ nas quintas séries do 18 grau, sēries consideradas crí ticas dentro do sistema escolar ${ }^{33}$. Por outro lado, assinalou-se tambēm que, dos serviços de saúde oferecidos pela SME, apenas duas atividades (controle da tuberculose e oftalmologia sanitária escolar) tèm - componente educativo desenvolvido de maneira siste 
mática. Contudo, o pessoal do ensino não participa do processo global de planejamento desses servi ços, como seria desejāvel.

Devido a circunstâncias ligadas à politi ca de pessoal da SME e à sua própria estrutura, o diretor da escola assume o caráter de elemento mul tiplicador do programa de saúde escolar. E o elo de ligação entre os técnicos responsáveis pelo pla nejamento, coordenação, execução e avaliação desse programa e a população escolar, a quem se dirigem todas as ações de saūde. O processo educativo ine rente a cada serviço de saūde (merenda escolar, atendimento médico e odontológicol concretiza-se através do diretor. Todavia, isto dependerá do grau de motivação e envolvimento desse diretor no que tan ge à programação de saūde escolar. Avaliações sucesșivas dessa programação mostram que, frequentemente, o conhecimento dos diretores a respeito dos serviços de saúde a serem desenvolvidos na sua escola é deficiente. Provavelmente, isso ocorre devido à forma como vêm sendo abordados e envolvidos na programação pelos técnicos do EA. Os diretores 
das escolas municipais, ou individuos por eles designados, recebem informações verbais e escritas so bre os objet1vos do programa em pauta, sobre seu de senvolvimento e o que se espera da escola, e a data prevista para as atividades. O contato entre os técnicos encarregados do aspecto educativo desses serviços de saúde e os diretores é, em geral, rápi do e bastante superficial. Outra variável a ser considerada refere-se à disponibilidade do diretor; geralmente ele è um executivo sobrecarregado de res ponsabilidades administrativas, obrigado a gastar grande parte do seu tempo com atividades burocrātí cas, muitas vezes sem contar com pessoal auxiliar necessārio para ser adequadamente envolvido no prọ cesso educativo da programação de saúde escolar.

Esta situação de fato mostra ser necessā rio que o programa de saúde escolar a ser executado a nivel de rede seja fruto do trabalho conjunto dos responsáveis pelas áreas de saúde e de ensino da SME.

Cabe ao educador de saúde pública conse- 
guir o envolvimento dos técnicos e autoridades da área do ensino municipal, no sentido de alertā-los para a importância e necessidade dos serviços de saúde escolar, como atividades altamente educattras que se refletem nos resultados do aproveitamento es colar. E ele ainda o responsável em mostrar aos $\underline{e}$ lementos da equipe de saúde escolar (médicos, dentistas, nutricionistas, educadores sanitārios, pro fessores, diretores e todo o pessoal auxiliar) o va lor da atuação de cada um e sua responsabilidade em termos da consecução dos objetivos do programa.

E necessārio que todo o pessoal envolvido no programa saiba que os serviços de saúde contribuem para a Educação em Saūde, não só informando os alunos sobre seu estado de saúde, mas tambēm através do contato dos alunos com todo o pessoal da equipe de saúde. Esse contato da criança com o mé dico, o dentista e demais membros da equipe determinará provavelmente, em larga escala, o seu compor tamento nos futuros contatos com serviços de saúde.

Segundo TURNER 47 , os professores preci- 
sam saber o que cada especialista significa para a criança e o que se espera do professor. E mais, que - professor, devido ao seu contato direto e diário com os alunos, está capacitado a prepará-los para seu contato com a equipe de saúde. Cabe ao profes sor explicar aos alunos a função e a importância dos profissionais de saúde, assim como verificar se as suas recomendações estão sendo cumpridas pelas crianças. Cabe ainda ao professor colaborar com outros serviços de saūde, como a merenda escolar. E desejāvel, portanto, que o professor acompanhe os alunos durante a merenda, aproveitando esse momento para explicar-lhes a razão pela qual são serví dos determinados alimentos e seu valor nutritivo; a maneira correta de portar-se à mesa, corrigin do comportamentos inadequados e promovendo outros que contribuem para a formação dos alunos, controlando e explicando os prejuizos causados pelo desperdicio; e, finalmente, estimulando-os a se interessarem por alimentos novos, cujo sabor lhesé des conhecido. Não basta alimentar as crlanças, è pre ciso que a merenda escolar seja uma experiência educativa para os alunos. Deve ser planejada cam es 
se objetivo, constituindo uma parte integrante do programa de Educação em Saúde na escola.

O desempenho esperado por parte de cada elemento que trabalha na escola, principalmente do professor, só será compreendido e realizado quando - educador de saúde püblica, como já se afirmou an teriormente, sendo um agente de mudança, conseguir envolver a todos, estimulando-os para uma ação integrada. Mais ainda, caberā ao educador de saúde pública o treinamento da equipe de saúde escolar, a fim de assegurar a realização de atividades que on tribuam para o êxito a longo prazo, dos serviços de saúde na escola.

\section{AMBIENTE ESCOLAR}

Se 0 ambiente pode ser definido como a so ma de forças externas que atuam sobre 0 individuo e se se reconhece que nenhum organismo pode exist1r isolado, parece claro que a criança e seu ambi ente são aspectos de um mesmo sistema em constante interação"l. Esta intimidade entre a criança e seu 
ambiente escolar explica alguns pontos que deveriam estar presentes na mente daqueles que militam na ā rea da Educação. Assim, se a criança tem que frequentar uma escola cujo ambiente não favorece seu crescimento, não protege sua saúde, nem lhe é atra ente, então seu comportamento não corresponderá ao que dela se espera ${ }^{4}$.

No século passado e no iniclo deste, os prédios escolares eram construídos apenas com o ob jetivo de abrigar os alunos. Pretendia-se que a cri ança se adaptasse ao ambiente escolar. Hoje, apesar de se reconhecer quanto esse conceito foi prejudicial, ainda é comum encontrarem-se escolas fun cionando em prédios adaptados, que nada têm em comum com sua função de ensino e de proteção e promo ção da saúde. OBERTEUFFER ${ }^{34}$ afirma que a explicação para as altas taxas de instabilidade nervosa, fadiga ocular, acidentes e doenças entre escolares pode, seguramente, estar relacionada com a planta física da escola, responsāvel por muitos desajusta mentos na infância. 
A manutenção de um ambiente saudável nas escolas é responsabilidade dos individuos relacionados direta ou indiretamente com a escola. Cabe, pois, às autoridades da SME, a responsabilidade de providenciar e oferecer à comunidade escolas cujas plantas físicas ofereçam condições de segurança e saúde para os alunos e para todo o pessoal. Aos di retores das unidades cabe a responsabilidade de ze lar pela manutenção da limpeza e segurança dos pré dios. Nos professores recai a responsabilidade de promover o uso do ambiente escolar de modo a desen volver nos alunos práticas conducentes à saúde. Aos alunos cabe fazer uso adequado de todas as facilidades da escola, cuidando pela sua conservação e mą nutenção. Finalmente, cabe à comunidade o papel de proteger a escola da ação de marginais (invasão, roubo, danificação das instalações). Um ambiente escolar sadio, indiretamente, significa Educação.

A tarefa do educador de saúde püblica è chamar a atenção de autoridades, corpo docente, cor po discente, pessoal administrativo, para o papel que cada um tem a desempenhar, mostrando que a es- 
cola è responsāvel pelo ambiente que ofer̂ece aos a lunos, assim como pelas implicações positivas ou ne gativas que esse mesmo ambiente acarretar para 0 processo educativo. Para que a escola consiga atingir tal objetivo é necessārio que o educador de saúde püblica envolva os técnicos responsäveis pelo ambiente escolar, de modo a desencadear nos vários niveis decisörios ações educativas conducentes a um ambiente físico satisfatōrio. Essas ações po dem variar em amplitude, indo desde a construção de prédios escolares até a manutenção da limpeza de suas calxas d'água. Nesse sentido, o educador de saúde püblica pode orientar o desenvolvimentode pro jetos educativos visando a atender necessidades pe culiares da reda como um todo ou de determinadas a reas ou mesmo unidades.

O desenvolvimento desta parte do programa de Educação em Saũde na escola permitirá que os alunos ganhem senso de responsabilidade e respeito pelo uso adequado da propriedade alheia; tornará claro que os alunos e professores são responsāveis pela manutenção da limpeza da escola; permitiráa 
alunos compreender que suas ações podem causar desconforto e perigo para outros; finalmente, despertará nos mesmos o gosto por um ambiente limpo, sadio e atraente.

\section{AMBIENTE EMOCIONAL}

- ambiente emocional da escola è fruto do relacionamento interpessoal diārio entre direção, corpo docente, corpo discente e pessoal administrativo. O tipo de relacionamento humano na sa la de aula depende principalmente do professor, que desempenha um papel positivo e preventivo na saúde mental de seus alunos47. Apesar do ambiente emocional ser responsabilidade de todo o pessoal que atua na escola, ele representa a figura chave do processo e é nele que o educador de saúde pública deve concentrar sua atenção. Desde que o professor aceite o ponto de vista de que sua influência pode ir além da mera ministração de conhecimentos e penetra o domínio do desenvolvimento total, ele passa a reconhecer infinitas possibilidades no ensino. 
A atmosfera da escola e da classe deveria ser tal que encorajasse a criança a dizer a ver dade ao invés da mentira, a ser corajosa ao Invés de covarde, a ser delicada ao invēs de rude, a ser honesta ao invēs de desonesta, a ser sociável a o invés de hostili34. Geralmente os professores controlam o comportamento das crianças na classe atra vés de medidas disciplinares baseadas no seu comportamento expresso, sem levar em conta as causas desse comportamento, o que pode levar a um relacio namento falso e tenso entre professores e alunos. Se o professor compreender as causas do comportamen to de seus alunos, sua atitude para com eles prova velmente será diferente, conduzindo a um relaciona mento mutuamente satisfatōrio ${ }^{9}$.

MARCONDES e colaboradores afirmam que a escola não significa apenas um local de alfabetiza ção, mas è também um "ambiente de socialização da criança, onde ela deve adaptar-se ao convívio de muitas outras crlanças, bem como aprender a respe $\underline{i}$ tar uma autorldade inteiramente diferente da que a té então conhecera (seus pais, em especial sua mãe), 
que è a professora. A maior parte das crianças nor mals acelta facilmente todas as contingências da $\mathrm{v} \underline{1}$ da escolar e realmente aprecia a escola e sua professora, desde que esta tenha os predicados minimos indispensáveis ao exercício do magistério primário" 26. O professor portador de um temperamento incontrolável, ou de crises de depressão, ou habitualmente nervoso, pode prejudicar a saúde emocional das crianças tão seriamente quanto aquele que sofra de doença contagiosa ${ }^{5}$.

No ambiente emocional, assim como no fisico, compete ao educador de saúde pública alertar os técnicos e autoridades da SME quanto à importân cia deste aspecto do programa de Educação em Saúde. E sua responsabilidade interessar-se pelos problemas oriundos dessa área, buscar soluções junto aos técnicos especializados e estimular sua difusão.

Para demonstrar a viabilidade da atuação do educador de saúde pública nesta dimensão do pro grama de Educação em Saúde na escola, a Disciplina Educação em Saũde pública da Faculdade de Saúde Pú 
blica da Universidade de São Paulo, desenvolveu 'yn projeto em uma unidade da rede estadual de ensino, sob a responsabilidade de um profissional da área de Educação em Saúde, visando ao "estabelecimentode um clima emocional favorável ao desenvolvimento in tegral da personalidade do aluno, através do relacionamento adequado entre aluno-professor-pessoal administrativo-pessoal técnico-pais de alunos" 28 .

Esse objetivo, a ser atingido a médio pra 20, foi dimensionado em termos de prioridades, ficando definido que no seu primeiro ano de implanta ção o projeto teria por objetivo especifico o rela cionamento entre professor-aluno, a nivel de sala de aula. Foi realizado treinamento dos professores, visando a capacitá-los a perceber, através de observação permanente, dois tipos de desvios de com portamento:

- os representados por alunos irriquietos, agressi vos e super-ativos, que perturbam as atividades escolares;

- os referentes àquelas crianças quietas, tristonhas, passivas, cujo comportamento, apesar de não 
constituir problema para o professor, pode ser au to-agressivo, progredindo em uma linha de agrava mento, freqdentemente de dificil recuperação.

Após o treinamento, os professores passaram a iden tificar os problemas de comportamento em sua classe que, posteriormente, foram analisados em grupo por eles, um psicólogo e um educador de saúde pública; sempre que possivel, chegou-se ao diagnóstico causal da situação. A orientação quanto ao procedimento adequado do professor, frente aos pro blemas comportamentais dos alunos, ficou a cargo do psicólogo. Durante alguns meses esse grupo se reu niu periodicamente, objetivando sempre a discussão e análise de novos problemas e a respectiva orientação, assim como a avaliação dos casos em andamen to.

Esse projeto implicou em mudança na roti na de trabalho do professor, uma vez que suas atividades diárias foram acrescidas de outras referen tes à observação individual dos alunos e discussões de casos nas reuniões mensais. 
Faz-se necessärio ressaltar o valor da $\underline{a}$ tuação do educador de saúde pública neste projeto; tendo identificado uma àrea critica no clima emocional da escola, motivou e envolveu os professores, o pessoal administrativo, assim como técnicos de outros serviços para que, atravēs de um trabatho conjunto, colaborassem na promoção e recuperação da saúde mental dos alunos. A avaliação do pró jeto evidenciou a validade da atuação do educador de saúde pública nessa dimensão do programa de Edụ cação em Saúde na escola, como elemento capaz de desencadear um processo de mudança e garantir seu èxito.

INTEGRAÇAO LAR-ESCOLA-COMUNIDADE

A escola é parte da comunidade, o que sig nifica que entre ambas não devem existir barreiras. As experiências em saúde que a criança vivencia fo ra da escola são parte da sua Educação em Saúde glo bal. A familia e a comunidade podem apoiar, refor çar ou anular o que é ensinado na escola47. Para 
que esse trabalho não seja prejudicado pela familia, è necessārio que o programa de Educação em Sạ úde na escola seja explicado e interpretado para os pais que, na medida do possivel, devem ser envol vidos em toda a programação.

Na SME, o relacionamento que existe entre as escolas e a comunidade limita-se a solicita ̧̧ões por parte das escolas às Administrações Regio nais (sub-prefeituras) da prestação de serviços, ou da aceitação passiva de serviços de saúde prestados pelas unidades sanitárias da comunidade (Secre taria da Saúde do Estado ou Secretaria de Higiene e Saúde da Prefeitura Municipal). Reuniões de pais e mestres nas escolas têm o objetivo único de entregar boletins. Reuniões sociais são iniciativas esporádicas e isoladas. Não existe uma programação que vise a fazer da escola um polo de atração comunltäria. Neste sentido, o educador de saúde pú blica tem amplo trabalho a realizar: colaborar pa ra que se crie uma politica de trabalho dentro da SME que valorize o relacionamento entre a escola e a comunidade; promover reuniões de pais e mestres 
para discutir problemas relativos à saúde do escolar e das familias; e, por fim, facultar esse relacionamento em programações rotineiras em todas as unidades escolares.

O desenvolvimento do programa de Educação em Saúde na escola não é trabalho para um único individuo; necessita da ação e colaboração de todos os profissionais que atuam na escola, direta ou indiretamente. Muito pouco pode ser feito sem a presença desses profissionais, assim como muito pouco pode ser feito sem a participação e cooperação de alunos e pais ${ }^{34}$.

Como a maioria das unidades escolares da SME está localizada nas zonas periféricas do município, onde são raros os locais de lazer, seria na tural e altamente educativo que elas funcionassem durante os períodos de ociosidade como centros de encontro social, educativo e de lazer para a comunidade. O comparecimento à escola deveria ser algo rotineiro e agradável para todos os pais e $n$ ão constituir apenas resposta a uma convocação ofici- 
al. As escolas municipais devem atuar como um centro comunitārio onde, atravēs de um trabalho conjunto do pessoal escolar com representantes da comunidade, são realizadas atividades sociais e educativas que correspondam, na medida do possível, às necessidades da escola e da própria comunidade. Sen do as escolas da SME, muitas vezes, as únicas agên cias oficiais de serviços da localidade, caberia a elas a responsabilidade de levar a comunidade a to mar iniciativas desse tipo. Entretanto, para que isso aconteça, torna-se necessārio que técnicos do ensino, tanto a nível central como local, conheçam as vantagens de um trabalho cooperativo entre esco la e comunidade. Cabe ao educador de saúde püblica a responsabilidade de mostrar a técnicos e auto ridades competentes as vantagens decorrentes dessa abordagem metodológica de ensino, não só para a es cola e para a comunidade, mas principalmente para os próprios alunos. Cabe-lhe, ainda, promover a $\underline{a}$ ção comunitária da escola, com o envolvimento de técnlcos disponíveis da SME que tenham condições de, através de uma participação ativa, colaborar na pro moção da integração entre lar-escola-comunidade. 
E ele ainda que deve apoiar iniciativas já testadas, estimulando a sua aplicação nas escolas municipais, oferecendo toda a assistência para que pos sam ser aperfeiçoadas e expandidas para toda a rede municipal de ensino. O tipo de atividade comunitária desenvolvida pelas unidades escolares da SME não deverá ser padronizado, uma vez que, embora as caracteristicas gerais das comunidades sejam semelhantes, as necessidadesecaracteristicas especificas de cada uma delas são diferentes. 0 impor tante è que a escola não permaneça omissa frente a uma dimensão do programa de Educação em Saúde na es cola, mas que assuma o seu verdadeiro papel de líder comunitário. A consecução desse objetivo resulta do trabalho do educador de saúde pública.

FUNÇðES DO EDUCADOR DE SAODE PÚBLICA

Tendo em vista as diversas atividades que cabem ao educador de saúde püblica desenvolver na SME frente às quatro dimensões do programa de Educação em Saúde na escola, as funções que the são î 
nerentes e que deverão ser desenvolvidas, com maior ou menor ênfase, dependendo da área em que estiver envolvido, são as seguintes ${ }^{4}$ :

1) assessorar o Secretário Municipal de Educação e os Diretores de Departamento nos assuntos referentes à Educação em Saúde na escola;

2) promover o levantamento das características sócio-econômico-culturais da clientela da SME;

3) realizar a análise, o estudo e o diagnóstico educativo do programa de saúde na escola;

4) elaborar o plano de Educação em Saúde na escola, atendendo às suas quatro dimensões: ensinc da saúde, serviços de saúde, ambiente escolar e in tegração lar-escola-comunidade e obedecendo aos objetivos do programa de saúde escolar vigente;

5) propor normas técnicas para o desenvolvimento a dequado desse plano, no que se refere à Educação em Saúde;

6) supervisionar a execução das atividades educati vas propostas;

7) estimular, planejar, participar e supervisionar programas de treinamento de pessoal técnicoe au xiliar na área da Educação em Saúde na escola; 
8) participar de grupos de trabalho multiprofissio nais dentro da SME, visando ao planejamento integrado do programa de Educação em Saúde na escola, com os demais programas da SME;

9) promover e participar de reuniões com líderes da comunidade, visando motivā-los para a solução dos problemas de saúde escolar diagnosticados na comunidade;

10) estimular a organização de comissões com a participação de técnicos da SME e representantes da comunidade, visando a abordagem, equacionamento e proposição de alternativas para a solução dos problemas de saúde na escola;

11) dar assessoria em relação aos aspectos educativos dos programas de Educação em Saúde na escola;

12) propor e realizar estudos diretamente ligados à sua ārea de ação.

Estas funções terão que ser adaptadas à realidade da SME, obedecendo às características da programação de saúde adotada pela SME, bem como aos recursos humanos e financeiros disponíveis. Desta forma, partindo das funções gerais do educador de 
saúde pública, os profissionais lotados na SME deverão adequá-las à própria situação de trabalho, vị sando sempre à promoção da saúde dos alunos da rede municipal de ensino. Parafraseando MARCONDES ${ }^{31}$, as funções do educador de saúde pública "podem variar em carāter e ênfase, de programa para programa ou de serviço para serviço. Podem às vezes duplicar as de outros profissionais, porque o especialista é responsável em profundidade por muitas das funções educativas com as quais outro pessoal frequentemente se encontra envolvido".

No Brasil, o educador de saúde pública vem desenvolvendo suas atividades predominantemente a nivel central e regional. Como a SME é um órgão cuja estrutura compreende apenas dois niveis (central e local) e tendo em vista as funções a serem desenvolvidas pelo educador de saúde pública dentro da SME, é preferível que ele se situe a nível central, participando com outros profissionais dos órgãos de assessoria técnica da SME.

Considerando que, em última análise, otrạ 
balho do educador de saúde püblica na SME visa a promoção da saúde dos alunos da rede municipal de ensino e que, para atingir esse objetivo, atua indiretamente atravēs da ação de outros técnicos, são estes ültimos que constituem a sua população-alvo. Nesse sentido, duas opções se apresentam para a lo calização do educador de saúde pública no quadro de pessoal da SME:

- localizá-lo no Gabinete do Secretário;

- localizá-lo nos três Departamentos que formam a estrutura básica da SME.

Na primeira alternativa estaria o educador de saúde pública fazendo parte dos órgãos de es tado maior do Secretário Municipal de Educação, co mo membro do seu corpo de assessores. Neste caso, não estaria subordinado a nenhum dos três Departamentos, podendo, entretanto, atingi-los através da autoridade do próprio secretário.

Na segunda alternativa, o educador de sa ũde püblica faria parte também da alta administração dos três Departamentos, como membro de sua as- 
sessoria tēcnica. Nesta situação, embora localizą do a nivel central, o educador de saúde pública es taria mais próximo da problemática que envolve a clientela do seu Departamento, podendo desenvolver um trabalho integrado com outros tēcnicos que, com diferentes especialidades, atuam na organização.

Recomenda-se que, nesta última opção, se tomem precauções para evitar duplicação ou colisão de ações por parte dos educadores de saūde pública, devendo estes observar uma politica de trabalho in tegradora. Assim, deve o programa de Educação em Saúde na escola da SME ser planejado, orientado e avaliado em conjunto pelos educadores de saúde pública do Departamento Municipal de Ensino, Departą mento de Educação Infantil e Departamento de Assis tência Escolar.

Cumpre lembrar que a atuação do educador de saūde püblica na SME dependerá da ação de outros profissionais a nível local, não necessariamente o diretor da escola, mas qualquer técnico que tenha condições de desempenhar as funções de multiplica- 
dor do programa de Eđucação em Saúde na escola. Re comenda-se, principalmente, que a ação desse ind1víduo não tenha características de trabalho voluntário, mas seja sistemática e regulamentada pelahie rarquia superior.

O número de educadores de saúde pública necessários à SME para realizar esse trabalho vai depender da intensidade e ènfase que imprimir à pro gramação de Educação em Saũde na escola, assim como das metas estabelecidas para a execução dessa pro gramação. Entretanto, partindo-se do principio pre conizado pela "National Health Survey"*, nos EUA, de que è necessário um educador de saúde pública pa ra cada 50.000 habitantes, e considerando-se que a SME contava em dezembro de 1975 com uma população escolar de 311.000 alunos entre pré-escolares e es colares 45 , pode-se dizer que a SME necessita, no mi nimo, de seis educadores de saúde pública para poder atender às necessidades de Educação em Saúde na escola. Note-se ser esta uma previsão baseada en da

* maRCONDES, R.S. et al. - Manpower planning for health education in the Americas. Washington, PanAmerican Health Organization, 1973 (mimeografado). 
dos de 1975, exigindo uma revisão periódica à medi da em que aumentar a população escolar. Este critério, que estabelece o número de profissionais em função da população a ser coberta, tem provado ser funcional; entretanto, no caso especifico, deve ser complementado, visto não atuar o educador de saúde pública apenas em função dos alunos, mas também de seus familiares, pessoal docente e administrativo e da comunidade em que está inserida a escola. Nesse sentido, seria aconselhāvel realizarem-se estudos visando à elaboração de outros critérios para - dimensionamento desse profissional em sistemas de ensino semelhantes à SME.

CONSIDERAÇðES FINAIS

Agências internacionais, como a OMS e a UNESCO, atribuem à escola a responsabilidade pelo de senvolvimento da Educação em Saúde, afirmando que "como agênclas especializadas no que se refere à $\underline{E}$ ducação e à Saúde, respectivamente, reconhecem a $\underline{E}$ ducação em Saúde nas escolas como parte importante 
da educação global e meio vital para a promoção da saúden ${ }^{n} 7$.

Cabe à escola, segundo TURNER ${ }^{4}$, desenvolver a capacidade do pensamento critico, ajudando as crianças a aprender como aprender, como enfrentar situações problemáticas e como adquirir no vos conhecimentos. A escola desempenha importante papel nos nossos dias, estimulando os alunos a viver uma vida independente, não por terem os pais se tornado omissos, mas em consequenencia da complexidade da sociedade atual, com opções mültiplas, que podem por em risco a vida e a saúde do indivíduo. Nesse sentido, é preciso que os alunos sejam preparados para saber distinguir, entre as várias opções que the são apresentadas, aquelas que mais thes convêm e, mais do que isso, para ter a maturí dade de aceitar as conseqtências de sua opção.

- Congresso Nacional sobre Saúde Escolar real1zado em Ottawa, em 197216, em suas recomendações finais afirma que "a curto prazo, o programa de Educação em Saúde deve preparar os jovens a fa- 
zer escolhas judiclosas ao longo de suas vidas, re ferentes aos hábitos alimentares, ao fumo, ao à Icool, ao uso de drogas, ao comportamento sexual, à higiene pessoal e à maneira como devem agir para e vitarem a doença. Deve ensiná-los, também, a lidar com situaçōes de "stress", a compreender e Iutar contra os problemas do seu ambiente e resolver os próprios problemas, a compreender as consequências pessoais e sociais de suas decisões e a darlhes a devida importância. A longo prazo, o programa de Educação em Saúde deve procurar inartir nos jovens atitudes que os acompanharão até a vida adulta; atitudes de preocupação com o bem-estar cọ mum e disposição para apoiar os problemas de Saúde Pública que transformarão aquelas preocupações em ação; atitudes de oposição às influências que pos sam prejudicar a saúde das pessoas e o progresso so cial".

Em ültima anālise, a Educação almeja influenclar a vida das pessoas, afetando sua maneira de fazer as colsas e melhorando suas vidas em rela ção ao passado. Procura melhorar o padrão-de-vida 
e prevenir as doenças. Concluindo com OBERTEUfFER ${ }^{34}$, "o programa de Educação em Saúde na escola deve situar-se diretamente no centro deste plano, constituindo uma parte integrante da estrutura educacional global, mas relacionada, primariamente, com a dimensão vital dos valores humanos". 
C O N C L U S ÕE S 
CONCLUSOES

1. A Educação em Saūde Pūblica è indispensãvel para a consecução dos objetivos da Educação e a $\underline{e}$ la deve ser integrada em todos os momentos da vi da do individuo.

2. A Secretaria Municipal de Educação da Prefeitura de são paulo não desenvolve ainda um programa global de Educação em Saũde na escola que abranja suas quatro dimensōes: ensino da saūde, serviços de saúde, ambiente escolar e integração lar-escola-comunidade.

3. Faltam à Secretaria Municipal de Educação, recursos humanos especializados para atender suas necessidades em termos de Educação em Saúde.

4. O educador de saūde püblica è o profissional ca pacitado para desenvolver a programação de Educação em Saúde na escola.

5. O educador de saúde pública deve atuar conjunta mente com equipes multiprofissionals. 
6. A rede municipal de ensino deve contar com elementos multiplicadores a nivel de unidade escolar, a fim de que a ação do educador de saúde pú blica possa se concretizar.

7. Estima-se em seis o número de educadores de saū de pública necessārios para dar atendimento às necessidades mínimas de programação da secretaria Municipal de Educação, neste momento.

8. Torna-se indispensável e urgente a criação do cargo de educador de saúde pública na Prefeitura Municipal de são Paulo, de modo a possibilitar sua utilização pela Secretaria Municipal de Educação. 


\section{SUMMARY}

Some of the historical aspects of Public Health Education are presented from its beginnings down to date when it can count on a specialized professional - the public health educator.

Concepts of Health. Education, Public Health Education and Health Education at School, as well as its goals, are considered.

The present situation of the Municipal Department of Education as regards Health Education is also described.

Finally the minimum number of public health educators necessary for the Department, considering its programmes, is estimated, their general line of work is layed out. 
REFERENCIAS BIBLIOGRAF ICAS 
REFERENCIAS BIBLIOGRAFFICAS

1. An APPROACH to evaluating school health education: introduction to the study. IN: SCHOOL HEALTH EDUCATION EVALUATION STUDY: LOS Ange les area 1954-1959: an evaluation research study. (s.n.t.), p. g-18.

2. BARBOSA, P. E RESENDE, C.B. de - Os serviços de saüde püblica no Brasil: 1800 a 1907 (Esboco Histórico). Rio de Janeiro, Imprensa Nacio nal, 1909 .

3. BICUDO PEREIRA, I.M.T. E GOTLIEB, S.L.D. - Atua ção do Ensino Municipal na ärea de saúde. (Tra balho apresentado ao 11 Congresso Brasileiro de Saüde Escolar, Rio de Janeiro, GB, 1973).

4. BIOCCA, S.M. - Aspectos doctrinários. IN: ARGEN TINA. Ministerio de Bienstar Social. Secre taria de Estado de Salud Pública. Bases de la educación para la salud. Buenos Aires, 1971 (Informes técnicos, sërie 1).

5. BROWNELL, C.L. - Principles of health education applied. New York, McGraw-Hill, 1949. 
6. BRITO-BASTOS, N.C. de - Educação sanitäria nos programas de saüde püblica. (Trabalho apresentado ao Congresso Sul-Riograndense de $\mathrm{Hi}$ giene, 2:, Porto Alegre, 1959).

7. CASTRo, A.L. - Educação sanitäria na Secretaria de Saüde de Säo Paulo; um estudo relativo à Coordenadoria da Saúde da Comunidade. São Paulo, 1970. (Monografia de Mestrado-Facul dade de Saüde Püblica, USP).

8. CLEMENTS, F.W. E MCCLOSKEY, B.P. - Child health: it's origins and promotion. London, Edward Arnold Publ., 1964.

9. COMmITTEe on Preventive Psychiatry of the Group for the Advancement of Psychiatry, Promotion of Mental Health in the Primary and Secondary Schools: an Evaluation of Four Projects, Report $n$ ? 18, January, 1951, p. 8. apud OBERTEUFFER, D. E BEYRER, M.K. ${ }^{34}$.

10. CONNER, F.E. - The status of health education in the nations's schools. IN: NATIONAL HEALTH COUNCIL - Health education in our schools to day: the need for agency action. New York, s/d., p. $1-4$.

11. DECRETO n: 66.623, de 22/05/1970 - Diärio oficial federal, Brasilia, 25 de maio, 1970. 
12. DECRETO n: 74.891, de $13 / 11 / 1974$ - Diärio Oficlal Federal, Brasilia, 14 de novembro, 1974.

13. DECRETO-LEI n: 430, de 08/07/1947 - IN: DECRE TOS, Decretos-Leis e Leis do Municiplo de São Paulo, do ano de 1947. São Paulo, 1947, p. 233-242.

14. DERRYBERRY, M. - Educación sanitäria: sus obje tivos y metodos. IN: ESTUDDS sobre evalua ción sanitäria. Washington, D.C., Organi zación Panamericana de la Salud, 1962, p. 1-9. (OPAS - Publ. cient. 73).

15. GARCIA, E.C., Relat. - Parecer n: $2.264 / 74$ Ens. da Saúde (1: e 2: graus) - aprovado em 06/08/1974. Documenta (165):63-83, 1974 .

16. GOBLE, M.N. - Recapitulation gēnérale: et main tenant, que devons nous faire? IN: CONFERENCE NATIONALE SUR L'HYGIENE EN MILIEU SCO LAIRE, Ottawa, 1972. Procés-verbaux. Ottawa, 1972. p. 79-84.

17. GUILBERT, J. - Structuration d'une vëritable è ducation pour la santé. Int.J.HIth. Educ., 15:232-37, 1972 .

18. MEALTH on the land. Int.J.HIth. Educ., 1: $161,1958$. 
19. JOHNS, E.B. et al. - Health for effective IIving. 5thed., New York, MeGraw-HIIl, 1970.

20. KLEINSCHMIDT, H.E. \& ZIMAND, S. Public Health education: it's tools and procedures. New York, MacMillan, 1953.

21. KRAUSZ, R.R. - Estudo de um novo profissional: - educador de saúde pública. São Paulo, 1974. (Tese de Doutoramento - Faculdade de Saúde Püblica, USP).

22. LEI n: 5.692, de 1971, e o ensino de 1! grau. Brasilia, Ministério da Educação e Cultura, 1971.

23. LE.I n: 7.037, de 13/06/1967. IN: DECRETOS, Decretos-leis e Leis do Municipio de são Paulo, do ano de 1967. São Paulo, 1967. P. $343-350$.

24. LEI n: 7.693, de 06/01/1972 - Diärio Oficial do Municipio, São Paulo, 07 de janeiro, 1972.

25. LEI n? 8.204, de 13/01/1975 - Diärio Oficial do Municipio, São Paulo, 14 de janeiro, 1975.

26. MARCONDES et al. - Problemas de escolaridade. IN: CONHECIMENTOS FUNDAMENTAIS DE PEDIATRIA. São Paulo, Rhodia, 1975. Cap. 12. P. 187-201. 
27. MARCONDES, R.S. - Educação sanitäria em nivel nacional. São Paulo, 1964. (Tese de Douto ramento - Faculdade de Higiene e Saúde Püb(ica, USP).

28. Coord. - Centro de experimentação e demonstração "Fernão Dlas Paes". Pla nos de trabalho e relatórios. São Paulo, Fa culdade de Saúde Püblica, USP, 1974.

29 . Educação em saüde na escola. São Paulo, Faculdade de Saüde Püblica, USP, 1971 (mimeografado).

30 . märia em educação sanitäria. Säo Paulo, 1968. (tese de Livre-Docência - Faculdade de Saüde Püblica, USP).

31. MARCONDES, R.S. E RAHM, E. - Funçöes dos educa dores sanitärios de São Paulo: relatório da sub-comissão de estudo. Arq. Fac. Hig., São Paulo, 13:201-218, 1959.

32. MEANS, R.K. - Health education: what, why and how. J. School HIth, 39:209-17, 1969.

33. A NOVA abordagem qualitativa do ensino. Escola Municipal, São Paulo, 4:5-10, 1974. 
34. OBERTEUFFER, D. E BEYRER, M.K. - School health education: a text book for teachers, nurses, and other professional personnel. 4 th ed. New York, Harper \& Brothers, 1966.

35. PIRRIE, D. E DALZELL-WARD, A.J. - A text book of health education. London, Tavistock Publ., 1962 .

36. PLANNING for health services: a guide for states and communities. Public health Bulletin, 304:57, apUd KLEINSCHMIDT, H.E. \& ZIMAND, 5.20 .

37. PROPOSED report on the educational qualifications of community health educators. Amer. J. publ. Hlth, 38:843-50, 1948 .

38. READ, M.S. - Malnutrition, hunger and behavior. (Part 11 - Hunger, school feeding programs, and behavior). J.Amer. diet. Ass, 63:38691, 1973.

39. ROBERTS, B.J. - Research in educational aspects of health programmes: its relationship with professional education and practice. Int. J. Hith Educ., 13 (suppl. 1), 1970.

40. ROSEN, G. - A history of public health. New York, M.D. Publ., 1958. 
41. ROSEN, G. - Human health, community life and rediscovery of the environment. Man: his environment and health. Amer. J. publ. Hith, 1 (supp 1. 1), 1964.

42. ROSENBURG, C.P. - Merenda escolar e crescimento. São Paulo, 1972. (Tese de Doutoramento - Faculdade de Saúde Püblica, USP).

43. RYAN, P.E. - The voluntary health agencies Pressures, problems, priorities, and a point of view on health education. IN: NATIONAL HEALTH COUNCIL. Health education in our schools today: the need for agency action. New York, s/d., p. 9-11.

44. SÃO PAULO. Secretaria de Educação e Cultura Departamento Municipal de Rnsino. Algumas consideracōes sobre a Lei Federal $5.692 / 71$ que fixa diretrizes e bases para o ensino de 1: e 2: graus e dá outras providénclas. São Paulo, s/d. (mimeografado).

45. SÃo PAULO (município) - Secretaria Municipal de Educação. Relatörio. São Paulo, 1975.

46. SÁO PAULO. Secretaria dos Negócios da Educação. Serviço de Saúde Escolar. Educação pa ra a saüde. Fundamentos e consideracões gerais. São Paulo, s/d. (mimeografado). 
47. TURNER, C.E. et al. - School health and health education. 6 th ed., Saint Louis, MIss, Mos by, 1970 .

48. UNIVERSIDADE DE SAO PAULO. Faculdade de Saúde Püblica. Disciplina Educação em Saüde Püblica. Recursos humanos para educacão em sa úde. São Paulo, 1973 (mimeografado).

49. UNIVERSIDADE DE SAO PAULO. Faculdade de Saüde Püblica. Disciplina Educação em Saüde Püblica. Programas de saūde para o sistema de ensino no Brasil. São Paulo, 1972.

50. WORLD HEALTH ORGANIZATION. Constitution. PubI. Hlth Rep., 61:1268-77, Washington, 1946. 